\title{
Redefining Social Constructs: An Exploratory Research on the Integration of Deaf Employees in the Philippine Metropolitan Workforce
}

\author{
Janine Sagala \\ University of Santo Tomas, Philippines \\ janine.sagala.med@ust.edu.ph |jpssagala.ust@gmail.com
}

\begin{abstract}
In the past, deafness has been entwined with groundless misconceptions from the distorted mentality shaped by social constructionism. Nevertheless, as movements on redefining the society began to materialize, much has been done to improve the status of the Deaf, as demonstrated by workplace inclusion and accommodations. Therefore, the study's primary purpose was to gauge the extent of this leap of social structure by investigating employer attitudes, capacities, struggles, and achievements in the employment of Deaf employees while taking into account the real essence of workplace inclusion. An exploratory study design was conducted with two subframes of participants: the hearing employers and Deaf employees. Recruitment of participants was achieved through purposive sampling, and data was gathered using a mixed-methods approach. Research instruments included Attitudes to Deafness Scale, Basic Need Satisfaction at Work, and Rosenberg Self Esteem Scale. Descriptive and exploratory analyses were used in the interpretation of results. Results showed a significant difference between the employers and the Deaf employees' perspectives, raising an issue on the separation between diversity and inclusion. Despite explicit support and favorable attitudes towards deafness, the Philippines has a long way to be called 'fully inclusive.'
\end{abstract}

Keywords: deafness; workplace integration; social constructionism

\section{Introduction}

With social constructionism that wraps reality, people are often trapped into identities that are not solely personal choice representations. Typically, identity formation stems from longstanding socio-cultural norms that are traditionally embedded in society. Hence, the binary system of 'normalcy and deviance' comes into play, with the latter being at a disadvantage.

The idea of disability as a deviant of 'ability' situates disabled individuals into marginalization or exclusion from the 'normal' society (Waldschmidt, Berressem, \& Ingwersen, 2017). Falling outside the range of acceptable standards, they are being strayed outside the peripheries of inclusion (Lejzerowicz, 2016). Accordingly, as physical or mental impairment impedes them from functioning normally, people with disabilities are subjected to a substandard integration system that limits their opportunities for education, work, and social life (Wong, 2016). 
The same thing happens to the d/Deaf people in a world dominated by hearing individuals. As they deviate in how people are wired, they are no exception to unwarranted judgments on account of damaged sensory modality. Notwithstanding its nature of invisibility, disclosure of deafness sets off negative suppositions and opinions (West, Low, \& Stankovic, 2015).

Historically and up to date, disability may be visible or invisible, carries a stigma of helplessness and dependency on others (Nieweglowski \& Sheehan, 2017). More than being marked destructively, disabled persons are also being drifted away from having full social participation (United Nations Department of Economic and Social Affairs, 2018).

Nevertheless, in the face of a distorted mentality, tides have turned through time, as movements on redefining the society began to materialize. Disability rights movements have sparked divergence on perspectives and consequently instigated a new way of looking at disability (Fraser, 2018). Beyond incapacitation, disabled people have then turned their confinements into farreaching horizons. Likewise, deafness has taken its new form. While it may not be accurate to all, many $\mathrm{d} /$ Deaf individuals have seen themselves as nothing less than the hearing and speaking populace.

\section{Literature Review}

\section{An Interplay of Lenses in the Perception of Deafness}

Deafness is construed in a multifaceted ideology where meaning is crafted based on which angle the spectator looks. Some may see it as a physical trait, while others may see it as a social concept. At one point, it is considered as deviance, but in another, it may suggest a cultural minority. It is in this sense that the idea of deafness steers controversies that are still bounded by ambiguities.

\section{Medical, Social and Cultural Models of Deafness}

Researchers identified various models of deafness, but two of the most accepted are the Medical and Social Models. In the medical approach, deafness is seen as a disability that needs treatment and rehabilitation. Along with this premise, the focus is on hearing loss and how to correct it using cochlear implants and hearing aids in conjunction with learning speech and lip-reading. Autonomy and self-sufficiency are considered indicative factors of being 'normal' in this model.

Contrary to the medical model, the social model draws its attention to difference rather than physical impairment. D/deaf people are only disabled by barriers created by society (Lejzerowicz, 2016). In this regard, the perceived norm merely implies prejudice rather than reality. Brice \& Strauss (2016) conveyed another perspective where deafness is viewed as a culture where distinctions are made between how a person with hearing loss identifies himself, which sets apart the "deaf " (lower case d) from the "Deaf" (upper case D). The former directs to an audiological condition of hearing while the latter claims a cultural identity, with sign language as a common form of communication.

The Deaf community, thus, share common attitudes and beliefs about themselves. However, since hearing loss is not a noticeable physical distinction, $\mathrm{d} /$ Deaf people cannot easily be discerned from the hearing majority. Some of them still choose to assimilate and try to blend in with the hearing society. In a study conducted by Kemmery and Compton (2014), where identity perception of four students with hearing loss was explored, variances were revealed in how d/Deaf people see themselves. An example is a student who perceived himself as a hearing individual with hearing aids and as hard of hearing when in challenging listening situations. He did not identify himself as a Deaf individual; however, he resorted to categorizing himself as a Deaf member of society to understand his needs. 


\section{Communication and Deafness}

The study by Powell-Williams (2018) proved that deaf individuals have different strategies for managing and choosing a particular communication mode. While some assume oral communication, others resort to lip-reading and signing. Data from the study revealed that a handful of respondents were sometimes compelled to normalize themselves when with hearing peers through rejecting assistance that may jeopardize their assimilation to the dominant hearing group. On the contrary, some are certain of their identities where they see themselves as belonging to a separate community with their language.

As the most commonly known alternative to oral communication, sign language allows the Deaf to express themselves fully in the most natural way possible. Through signing, the Deaf can communicate within themselves and feel a sense of belongingness. The theory of Symbolic Interactionism (SI) by Mead explains that on top of verbal means, interpretation of meaning is also bounded by other contributing factors like gestures and context. It emphasizes the symbolic interaction that creates order and sense in people's daily lives (Pranata, Latif \& Fanani 2019). As for the Deaf community, meaning is formed in interaction through the acceptance of Sign Language and Lip-reading (Pranata, Latif \& Fanani 2019).

Sadly, even though Deaf people have their means to communicate within themselves through sign language, the problem arises when they interact with hearing and speaking people. Circumstances may sometimes compel the Deaf to use verbal language by saying with their mouths and hand movements to be easily understood. As an effect of this adjustment, modification of communication patterns develops, which creates a wrong impression that they are having trouble communicating. When communication becomes ineffective, interpersonal relationships and socialization may then be negatively influenced.

\section{Deafness in the Workplace}

Concerning the stigmatization of $\mathrm{d} /$ Deaf individuals within variant contexts, a strong trajectory to examine in their life development is their employment status. Work is a fundamental right, and everyone should be able to exercise it. As stated by Opoku, Mprah, Dogbe, Moitui, \& Badu (2017), having the opportunity to work not only contributes to the nation's economic growth but, more importantly, advances one's status quo and fosters self-sufficiency, a sense of self-worth, and selfexpression. Employment of d/Deaf is thus key for their empowerment, independence, and overall well-being. On this basis, movements on inclusion stressed unrestricted access to employ the d/Deaf, forbidding forms of discrimination, and warranting equal workplace opportunities.

Unfortunately, despite having d/Deaf inclusion initiatives, available statistics still show a low employment rate of this population. According to the Yang-Tan Institute at Cornell University's analysis of 2017 American Community Survey data, only around 39\% of those with hearing impairment work full time. World Health Organization further claimed worse situations in developing countries, where higher unemployment rates exist among the d/Deaf. Among those who are employed, $\mathrm{d} /$ Deaf individuals are in the lowest grades of employment. Consequently, as $\mathrm{d} /$ Deaf people have limited work access, destitution becomes higher than hearing peers (United Nations Department of Economic and Social Affairs, 2018). They may also be deprived of access to other general services, including formal education, and therefore, their social integration becomes limited (Turcotte, 2014).

Baum (2015) suggested that $d$ /Deaf may struggle with employer bias that may affect employment, promotion, and task delegation. According to studies, common reasons for resistance include communication difficulties, insufficient education, and employer mindset (Perkins-Dock, Battle, Edgerton, \& McNeill, 2015). The d/Deaf may primarily find it challenging to penetrate 
interactions, thereby limiting opportunities for them to be fully engaged in their tasks (Shuler et al., 2014).

An ethnographic study of Deaf workers at a popular Indian coffee chain called Café Coffee Day discovered that Deaf workers felt stagnation and isolation in their roles. In contrast, employers expressed a positive perception of them (Friedner's, 2013), hence, revealing contrasting perspectives between the two groups. Furthermore, in a study by Stokar \& Orwat (2018), Deaf workers consistently expressed a desire for improving communication patterns at the workplace.

\section{Status of Deaf in the Philippines}

In the Philippines, several policies have been mandated to address issues concerning the Rights of Persons with Disability (PWDs), including the Deaf sector. Examples are the Magna Carta for Persons with Disability (PWDs) and Executive Order No. 417. These were implemented to ensure rehabilitation, self-development, and self-reliance of disabled persons by developing their total well-being and integration in the mainstream society (Silva-dela Cruz \& Calimpusan, 2018).

Intended for the Deaf Filipinos, Republic Act 11106, known as Filipino Sign Language (FSL) Act, was formally signed into law last November 2018 (Ranada, 2018). This act orders FSL to be used in institutions like schools, government offices, and television when communicating to the Filipino Deaf. This directive claims to be an access point to which Deaf individuals may be socially integrated.

Nevertheless, despite the efforts being initiated, opportunities for the Deaf in the Philippines, particularly in employment, remain questionable. While previous research may link the situation to lack of education, actual figures and studies are still inadequate. It then sets off the question, "Is the Philippines a Deaf-inclusive country, or does inclusion stop on pen and paper?"

\section{Conceptual Framework}

The study was anchored on interrelated concepts, starting with the Deaf's characteristics and progressing on the impact of social identification. It delved into relationships that coexist among variables, on the account that low results on one variable could induce indirect proportions to another. Existing policies and initiatives were probed and how these were enforced in terms of concrete social participation of Deaf individuals, as evident in workforce inclusion.

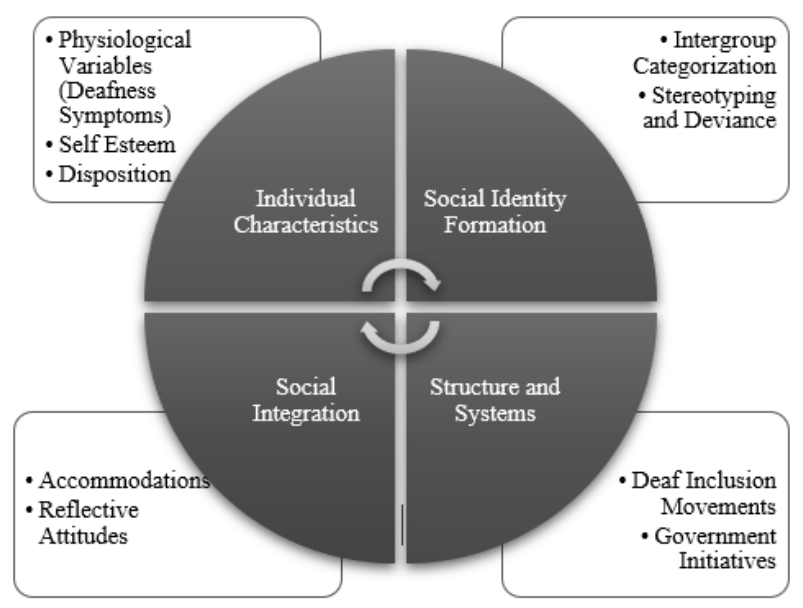

Figure 1. Conceptual Framework 


\section{Method}

\section{Problem Statement}

Given the wide-ranging topic of disability, this research was intended to focus only on the current view of deafness, a controversial yet overlooked subject matter, especially in a third world country where social conditions aggravate the problem. With the latest estimates of the World Health Organization (2018), 466 million people in the world have disabling hearing loss. The most significant prevalence is seen in regions of South Asia, Asia Pacific, and Sub-Saharan Africa. In the Philippines alone, it is estimated that hearing impairment, including mild forms, is established at $28.8 \%$ of the general population (Better Hearing Philippines, Inc., 2005). However, it is surprising that despite the growing number of the d/Deaf community in the country, studies about their social status remain scarce, especially in terms of social participation. With this underlying principle, the researcher decided to tap on employment as the focal measure of social participation. The collected data was intended to be an insightful groundwork from which further studies can be conducted.

The study's general purpose was to systematically investigate employer attitudes, accommodations, struggles, and achievements in the employment of Deaf employees, in consideration of the real essence of workplace inclusion in the companies situated in Metro Manila. Further to this, it was the study's objective to understand the relationship between employers and employees' perspectives regarding inclusion for the improvement of the inclusion strategies within organizations.

For this study, the following questions were explored:

1. What are the factors that affect inclusive attitudes towards hiring Deaf employees?

2. What are the perceived difficulties and gains on Deaf employment?

3. How does the self-esteem of employers affect their inclusiveness to Deaf?

4. How does the self-esteem of employees affect their feeling of being included?

5. Is there a significant difference between the perspectives of the employers and Deaf employees regarding accommodation?

\section{Scope and Limitations}

Since there are many variations of deafness, the researcher targeted only those with severe to profound loss with Filipino Sign Language as the primary means of communication. This measure was due to the researcher's assumption that accommodations may have less impact on those with milder degrees of hearing loss who use oral communication.

Although the study employed a mixed approach on both participant subframes, the interview part for the Deaf participants was in written form because of the time constraint for the researcher to learn Filipino Sign Language (FSL) before the data collection.

Another significant limitation of the study is the tendency of participants for social desirability. Despite the assurance of anonymity, their tendency to steer social desirability was out of the researcher's control and could have led to possible bias in the study.

\section{Participants}

The study was comprised of two subframes: hearing employers and Deaf employees. For the first subframe, responses were gathered from sixty-nine employers, directors, owners, managers, or HR practitioners from various Metro Manila industries. Target companies included local and international firms, representing diverse groups such as Administrative Services, Accommodation, and Food Services, Finance and Insurance, Construction Industries, Healthcare Services, 
Education, Manufacturing Industries, Information and Communication, Technical and Scientific Services, and others. Participation was voluntary, anonymous, and confidential.

The second subframe included twenty-one selected Filipino Deaf employees who use Filipino Sign Language (FSL) as the primary language. Qualification considered those with hearing loss substantial to impede auditory communication. The ability to read and write in English was also an inclusion criterion. Participation was voluntary, anonymous, and confidential.

\section{Design}

The study employed an exploratory cross-sectional design with a mixed-method approach to data collection, analysis, and synthesis.

The survey's demographic part consisted of the participants' age, sex, educational attainment, employment status, and workplace industry. From these variables, the researcher explored points of analysis and themes for subsequent discussion.

For the employer participants, the first research instrument was "Attitudes to Deafness," a twentytwo-item scale designed for administration to human resource professionals. It comprises statements from deaf people in literature and from a group discussion of the deaf regarding their shared experiences in hearing individuals' attitudes towards them (Cooper, \& Rose, \& Oliver, 2004). The second instrument was "Rosenberg Self-Esteem Scale," a 10-item scale that determines self-worth by measuring positive and negative views about the self. For supplementary information, fifteen randomly selected participants were invited for an interview.

The research instruments were the "Rosenberg Self-Esteem Scale" and "Basic Need Satisfaction at Work for the employee participants." The latter is a 21 -item scale designed to express employees' experiences and feelings towards their job, accounting for the concepts of competence, autonomy, and relatedness. Through this scale, the Deaf participants expressed their real status in their workplace and disclosed if the real essence of inclusion exists. All participants were also invited to complete a written interview. The researcher then attempted to merge the data sets bringing individual results together in a rational, logical, and comprehensive discussion.

\section{Materials and Procedure}

Before recruiting participants, the researcher sought approval from the University of Santo Tomas Institutional Review Board (IRB). The cover letter, consent form, demographic sheets, and quantitative questionnaires for the first subframe were converted into electronic records upon approval. Paper forms were utilized for the second subframe as the researcher anticipated a more challenging recruitment process for this group. Surveys were anonymous and coded through numbers.

The participants were required to agree to the terms, as stated by the consent form. The survey took around 15 to 20 minutes to finish; incentive was not given to the participants. All responses were directed to an excel file and exported to an SPSS file format for statistical analyses.

For the interview part, the researcher randomly invited previously recruited participants for a meeting based on their convenience and privacy preferences. The researcher provided a small gift for face-face interviews.

\section{Analysis}

Results were analyzed using the descriptive analysis to determine the factors that framed employer attitudes. The researcher also extracted significant statements, clustered them, and formed themes, 
alongside a synthesis of remarks on observations. Exploratory data analysis was also performed to uncover relationships between these factors and the other variables in the study. A passwordprotected computer and software were used in the process of recording, consolidating, and storing data.

\section{Results}

\section{Demographic Results}

Subframe 1: Employers

Demographic information from the first subframe of participants included age, sex, educational attainment, organizational role, Deaf hiring experience, and industry categorization. Of the 85 surveys sent electronically, 69 surveys were completed for an $81 \%$ return rate. For the 69 valid surveys, there were 47 females $(68.1 \%)$ and 22 males (31.9\%). The participants' predominant age range was $18-29$ years old, $48.5 \%$, followed by ages $30-41$ at $42.4 \%$, and finally, $42-53$ years old at $9.1 \%$. The participants' educational levels included $78.3 \%$ with a bachelor's degree, $18.8 \%$ with a master's degree, $1.4 \%$ had a certificate or training program, and another $1.4 \%$ completed high school or equivalent program. $68.8 \%$ of the respondents were managers/supervisors, $22.4 \%$ were HR professionals, and $9 \%$ were executives or owners. Half of the total respondents indicated work experience of 1-3 years (44.9\%), while other groups reported 4-6 years and less than a year, with $31.9 \%$ and $15.9 \%$, respectively. In terms of Deaf employment, only $27.9 \%$ experienced hiring or working with a signing Deaf employee. Industry categorizations were diverse, but the top industries were financial and insurance at $21.7 \%$, service activities at $20 \%$, information and communication at $11.6 \%$, and administrative service at $10.1 \%$.

Table 1. Demographic Factors vs Attitude

\begin{tabular}{|c|c|c|c|c|c|}
\hline & Mean & Standard Dev. & Pearson Chi & P-Value & Decision \\
\hline Age & $1.60(30-41)$ & .653 & \multirow{2}{*}{$5.917^{*}$} & \multirow{2}{*}{.005} & \multirow{2}{*}{ Significant } \\
\hline Attitude & 2.88 & .322 & & & \\
\hline & Mean & Standard Dev. & Pearson Chi & P-Value & Decision \\
\hline Sex & 1.31 (Female) & .469 & \multirow{2}{*}{1.566} & \multirow{2}{*}{.211} & \\
\hline Attitude & 2.88 & .322 & & & Significant \\
\hline & Mean & Standard Dev. & Pearson Chi & P-Value & Decision \\
\hline Industry & 7.14 & 3.46 & \multirow{2}{*}{7.490} & \multirow{2}{*}{.639} & \\
\hline Attitude & 2.88 & .322 & & & Significant \\
\hline & Mean & Standard Dev. & Pearson Chi & P-Value & Decision \\
\hline $\begin{array}{l}\text { Deaf } \\
\text { Employment }\end{array}$ & .279 (no) & .452 & \multirow[t]{2}{*}{.411} & \multirow[t]{2}{*}{.521} & \multirow{2}{*}{$\begin{array}{l}\text { Not } \\
\text { Significant }\end{array}$} \\
\hline Attitude & 2.88 & .322 & & & \\
\hline
\end{tabular}

Among the demographic factors that were tapped, only age appeared to have a statistically significant relationship with attitudes towards deafness. This data infers that those in the range of 30-41 years old are more likely to have positive perceptions about the Deaf and hence, potentially more optimistic in hiring Deaf employees.

Subframe 2: Deaf Employees

Same demographic measures were obtained from the second group, with the addition of job status. Twenty-one Deaf employees participated in the research. Of these, $52.4 \%$ were males, and $47.6 \%$ were females. More than half $(57.1 \%)$ of those who responded fell within the range of 18-29, $38.1 \%$ were $30-41$, and $4.8 \%$ came from the $42-53$ age group. $71.4 \%$ graduated with a bachelor's degree for educational attainment while others had a high school diploma and certificate or training program, with shares of $19 \%$ and $9.5 \%$, respectively. Most participants were production or service staff, comprising of $57.1 \%$. 38.1\% were professionals, and only $4.8 \%$ were managers or supervisors. Almost all of them had full-time jobs at $81 \%$. Years of service were reported to range 
from $1-3$ years at $45 \%$, less than a year at $22.7 \%$, 4-6 years at $14.3 \%, 7-10$ years at $9.5 \%$, and above ten years at $4.8 \%$. Deaf participants came mostly from the service industry at $28.6 \%$ and administrative support at $14.3 \%$.

The Common Link Between Self Esteem and Attitude Towards Inclusion

Table 2. Rosenberg Self-Esteem Scale (RSES) of Employers

Possible score range per item is $1-4$, and the possible total score range is 10-40. Higher mean scores suggest bigher seff-esteent

\begin{tabular}{|c|c|c|c|c|c|}
\hline \multirow{2}{*}{ ITEMS } & \multicolumn{4}{|c|}{ PERCENTAGES (\%) } & \multirow{2}{*}{ MEAN } \\
\hline & SD & D & A & SA & \\
\hline 1. On the whole, I am satisfied with myself. & 1.4 & 7.2 & 49.3 & 42 & 3.3188 \\
\hline 2. At times, I think I am no good at all. & 17.4 & 43.5 & 34.8 & 4.3 & 2.2609 \\
\hline 3. I feel that I have a number of good qualities. & 1.4 & 5.8 & 46.4 & 46.4 & 3.3768 \\
\hline $\begin{array}{l}\text { 4. I am able to do things as well as most other } \\
\text { people. }\end{array}$ & 1.4 & 8.7 & 44.9 & 44.9 & 3.3333 \\
\hline 5. I feel I do not have much to be proud of. & 37.7 & 42.0 & 14.5 & 5.8 & 1.8841 \\
\hline 6. I certainly feel useless at times. & 27.5 & 40.6 & 23.2 & 8.7 & 2.1304 \\
\hline $\begin{array}{l}\text { 7. I feel that I'm a person of worth, at least on an } \\
\text { equal plane with others. }\end{array}$ & 2.9 & 4.3 & 47.8 & 44.9 & 3.3478 \\
\hline 8. I wish I could have more respect for myself. & 19.1 & 39.7 & 25.0 & 16.2 & 2.3824 \\
\hline 9. All in all, I am inclined to feel that I am a failure. & 58.0 & 27.5 & 10.1 & 4.3 & 1.6087 \\
\hline 10. I take a positive attitude toward mvself. & 2.9 & 4.3 & 26.1 & 66.7 & 3.5652 \\
\hline TOTAL SCORE & & & & & 27.2084 \\
\hline
\end{tabular}

Table 3. Attitudes to Deafness Scale (ATDS) of Employers

\begin{tabular}{|c|c|c|c|c|c|c|c|}
\hline ITEMS & VAI & ID PE & RCEI & $\mathbf{T}(\%$ & & & MEAN \\
\hline & 1 & 2 & 3 & 4 & $\mathbf{5}$ & 6 & \\
\hline $\begin{array}{l}\text { 1. Deaf couples should receive genetic counselling } \\
\text { to avoid having deaf children. }\end{array}$ & 11.6 & 10.1 & 11.6 & 20.3 & 21.7 & 24.6 & 4.0435 \\
\hline $\begin{array}{l}\text { 2. Deaf children should learn to speak to } \\
\text { communicate with hearing parents. }\end{array}$ & 11.6 & 18.8 & 15.9 & 14.5 & 7.2 & 31.9 & 3.8261 \\
\hline 3. I would like to have more deaf friends. & 0 & 1.5 & 7.4 & 23.5 & 30.9 & 36.8 & 4.9412 \\
\hline 4. Deaf schools and deaf clubs create deaf 'ghettos'. & 34.8 & 29.0 & 10.1 & 11.6 & $4 . \hat{3}$ & 10.1 & 2.5217 \\
\hline $\begin{array}{l}\text { 5. Deaf people should learn speech rather than sign } \\
\text { language. }\end{array}$ & 31.9 & 21.7 & 23.2 & 15.9 & 1.4 & 5.8 & 2.5072 \\
\hline 6. Deaf people are handicapped. & 33.3 & 10.1 & 18.8 & 24.6 & 7.2 & 5.8 & 2.7971 \\
\hline $\begin{array}{l}\text { 7. More research should be done to find cures for } \\
\text { deafness. }\end{array}$ & 5.8 & 2.9 & 1.4 & 7.2 & 18.8 & 63.8 & 5.2174 \\
\hline 8. Deaf children should be taught in sign language. & 2.9 & 2.9 & 8.7 & 17.4 & 34.8 & 33.3 & 4.7826 \\
\hline $\begin{array}{l}\text { 9. Hearing children of deaf parents are at risk of } \\
\text { emotional deprivation. }\end{array}$ & 26.1 & 21.7 & 21.7 & 10.1 & 11.6 & 8.7 & 2.8551 \\
\hline 10. Deaf people are safe drivers. & 8.7 & 20.3 & 39.1 & 17.4 & 10.1 & 4.3 & 3.1304 \\
\hline 11. I would like to have more deaf colleagues. & 0 & 1.5 & 10.4 & 32.8 & 23.9 & 31.3 & 4.7313 \\
\hline 12. Deaf people should learn to lip read. & 4.3 & 7.2 & 15.9 & 18.8 & 21.7 & 31.9 & 4.4203 \\
\hline $\begin{array}{l}\text { 13. Interpreters should be available for deaf people at } \\
\text { work }\end{array}$ & 8.8 & 8.8 & 10.3 & 25.0 & 19.1 & 27.9 & 4.2059 \\
\hline
\end{tabular}




\begin{tabular}{|l|l|l|l|l|l|l|l|}
\hline $\begin{array}{l}\text { 14. Deaf people should automatically receive help in } \\
\text { their home environment. }\end{array}$ & 2.9 & 4.3 & 11.6 & 29.0 & 17.4 & 34.8 & 4.5797 \\
\hline $\begin{array}{l}\text { 15. All deaf people should be offered corrective } \\
\text { surgery. }\end{array}$ & 4.3 & 2.9 & 15.9 & 27.5 & 20.3 & 29.0 & 4.4348 \\
\hline $\begin{array}{l}\text { 16. Training more mental health professionals to } \\
\text { work with deaf clients would be a waste of time. }\end{array}$ & 69.6 & 18.8 & 4.3 & 1.4 & 1.4 & 4.3 & 1.5942 \\
\hline $\begin{array}{l}\text { 17. Having a deaf colleague would cause problems in } \\
\text { the workplace. }\end{array}$ & 50.0 & 30.9 & 13.2 & 2.9 & 1.5 & 1.5 & 1.7941 \\
\hline 18. Deaf people are physiologically impaired & 30.4 & 23.2 & 14.5 & 23.2 & 4.3 & 4.3 & 2.6087 \\
\hline 19. Deaf people should not be viewed as "impaired." & 2.9 & 5.8 & 15.9 & 14.5 & 30.4 & 30.4 & 4.5507 \\
\hline $\begin{array}{l}\text { 20. I would like to see more deaf people at the } \\
\text { clubs/societies I attend. }\end{array}$ & 0 & 1.4 & 4.3 & 15.9 & 37.3 & 40.6 & 5.1159 \\
\hline 21. Having a deaf friend would be difficult. & 33.3 & 27.5 & 20.3 & 11.6 & 5.8 & 1.4 & 2.3333 \\
\hline 22. Deaf people have their own culture. & 8.7 & 21.7 & 14.5 & 26.1 & 13.0 & 15.9 & 3.6087 \\
\hline \multicolumn{1}{|l|}{ 1 - Strongly Disagree; 2 - Disagree; 3 - Slightly Disagree; - Slightly Agree; 5 - Agree; 6 - Strongly Agree } \\
\hline
\end{tabular}

Table 4. Self Esteem vs. Attitude of Employers

\begin{tabular}{|l|l|l|l|l|l|}
\hline & Mean & $\begin{array}{l}\text { Standard } \\
\text { Dev. }\end{array}$ & Pearson Chi & P-Value & Decision \\
\cline { 1 - 5 } Self-Esteem & 3.71 & .322 & .183 & .131 & $\begin{array}{l}\text { Not } \\
\text { Significant }\end{array}$ \\
\hline Attitude & 2.88 & .322 & & & . \\
\hline
\end{tabular}

The hearing employers' overall score indicated a high percentage value revealing generally high self-esteem among the participants. Responses yielded high percentage scores on positive statements 1, 3, 4, 7, and 10, while low scores were indicated on negative items 2, 5, 6, 8, and 9 . Comparison of the Rosenberg Self-Esteem Scale (RSES) scores with the Attitude to Deafness Scale (ATDS) scores was statistically insignificant.

Table 5. Rosenberg Self-Esteem Scale (RSES) of Employees

Possible score range per item is 1-4, and the possible total score range is 10-40. Higher mean scores suggest bigber seffesteem

\begin{tabular}{|l|l|l|l|l|l|l|}
\hline \multirow{2}{*}{ ITEMS } & \multicolumn{3}{l|}{ VALID (\%) } & \multirow{2}{*}{ MEAN } \\
\cline { 2 - 6 } & SD & D & A & SA & \\
\hline 1. On the whole, I am satisfied with mvself. & 0 & 0 & 66.7 & 33.3 & 3.3333 \\
\hline 2. At times, I think I am no good at all. & 0 & 52.4 & 38.1 & 9.5 & 2.5714 \\
\hline 3. I feel that I have a number of good qualities. & 0 & 0 & 57.1 & 42.9 & 3.4286 \\
\hline $4 . \quad$ I am able to do things as well as most other people. & 0 & 4.8 & 47.6 & 47.6 & 3.4286 \\
\hline 5. I feel I do not have much to be proud of. & 9.5 & 42.9 & 38.1 & 9.5 & 2.4762 \\
\hline 6. I certainly feel useless at times. & 15.0 & 40.0 & 35.0 & 10.0 & 2.4000 \\
\hline $\begin{array}{l}\text { 7. I feel that I'm a person of worth, at least on an equal } \\
\text { plane with others. }\end{array}$ & 0 & 4.8 & 52.4 & 42.9 & 3.3810 \\
\hline 8. I wish I could have more respect for mvself. & 0 & 4.8 & 28.6 & 66.7 & 3.6190 \\
\hline 9. All in all, I am inclined to feel that I am a failure. & 28.6 & 28.6 & 33.3 & 9.5 & 2.2381 \\
\hline 10. I take a positive attitude toward myself. & 0 & 4.8 & 19.0 & 76.2 & 3.7143 \\
\hline TOTAL SCORE & & & & 30.5905 \\
\hline
\end{tabular}


Table 6. Basic Need Satisfaction at Work (W-BNS) of Employees

\begin{tabular}{|c|c|c|c|c|c|c|c|c|}
\hline \multirow{2}{*}{$\begin{array}{l}\text { IITEMS } \\
\text { AUTONOMY }\end{array}$} & \multicolumn{7}{|c|}{ VALID PERCENT (\%) } & \multirow[t]{2}{*}{ MEAN } \\
\hline & & & & & & & & \\
\hline & 1 & 2 & 3 & 4 & 5 & 6 & 7 & \\
\hline $\begin{array}{l}\text { 1. I feel like I can make a lot of inputs to deciding how my job } \\
\text { gets done. }\end{array}$ & 0 & 0 & 4.8 & 19.0 & 19.0 & 19.0 & 38.1 & 5.6667 \\
\hline 5. I feel pressured at work. (R) & 0 & 0 & 0 & 19.0 & 23.8 & 33.3 & 23.8 & 5.6190 \\
\hline 8. I am free to express my ideas and opinions on the job. & 0 & 0 & 4.8 & 4.8 & 23.8 & 33.3 & 33.3 & 5.8571 \\
\hline 11. When I am at work, I have to do what I am told. (R) & 0 & 0 & 4.8 & 9.5 & 9.5 & 14.3 & 61.9 & 6.1905 \\
\hline 13. My feelings are taken into consideration at work. & 0 & 0 & 0 & 14.3 & 23.8 & 23.8 & 38.1 & 5.8571 \\
\hline 17. I feel like I can pretty much be myself at work. & 0 & 0 & 0 & 4.8 & 19.0 & 33.3 & 42.9 & 6.1429 \\
\hline $\begin{array}{l}\text { 20. There is not much opportunity for me to decide for myself } \\
\text { how to go about my work. (R) }\end{array}$ & 9.5 & 4.8 & 14.3 & 23.8 & 28.6 & 9.5 & 9.5 & 4.2381 \\
\hline \multicolumn{9}{|l|}{ COMPETENCE } \\
\hline & 1 & 2 & 3 & 4 & 5 & 6 & 7 & \\
\hline 3. I do not feel very competent when I am at work. (R) & 14.3 & 0 & 9.5 & 28.6 & 14.3 & 19.0 & 14.3 & 4.4286 \\
\hline 4. People at work tell me I am good at what I do. & 0 & 0 & 0 & 0 & 33.3 & 33.3 & 33.3 & 6.0000 \\
\hline 10. I have been able to leam interesting new skills on my job. & 0 & 0 & 0 & 0 & 14.3 & 9.5 & 76.2 & 6.6190 \\
\hline 12. Most days I feel a sense of accomplishment from working. & 0 & 0 & 9.5 & 9.5 & 19.0 & 28.6 & 33.3 & 5.6667 \\
\hline $\begin{array}{l}\text { 14. On my job I do not get much of a chance to show how } \\
\text { capable I am. (R) }\end{array}$ & 9.5 & 0 & 14.3 & 28.6 & 9.5 & 19.0 & 19.0 & 4.6190 \\
\hline 19. When I am working I often do not feel very capable. (R) & 9.5 & 9.5 & 9.5 & 33.3 & 23.8 & 4.8 & 9.5 & 4.0476 \\
\hline \multicolumn{9}{|l|}{ RELATEDNESS } \\
\hline & 1 & 2 & 3 & 4 & 5 & 6 & 7 & \\
\hline 2. I really like the people I work with. & 0 & 0 & 0 & 4.8 & 23.8 & 23.8 & 47.6 & 6.1429 \\
\hline 6. I get along with people at work. & 0 & 0 & 0 & 14.3 & 19.0 & 38.1 & 28.6 & 5.8095 \\
\hline 7. I pretty much keep to myself when I am at work. (R) & 0 & 0 & 0 & 4.8 & 23.8 & 38.1 & 33.3 & 6.0000 \\
\hline 9. I consider the people I work with to be my friends. & 0 & 0 & 0 & 4.8 & 23.8 & 33.3 & 38.1 & 6.0476 \\
\hline 15. People at work care about me. & 0 & 0 & 9.5 & 19.0 & 23.8 & 23.8 & 23.8 & 5.3333 \\
\hline 16. There are not many people at work that I am close to. (R) & 9.5 & 0 & 4.8 & 33.3 & 23.8 & 9.5 & 19.0 & 4.6667 \\
\hline 18. The people I work with do not seem to like me much. (R) & 19.0 & 4.8 & 4.8 & 19.0 & 23.8 & 9.5 & 19.0 & 4.2857 \\
\hline 21. People at work are pretty friendly towards me. & 4.8 & 4.8 & 0 & 0 & 19.0 & 23.8 & 47.6 & 5.8571 \\
\hline \multicolumn{9}{|c|}{ 1- not at all true; 4- somewhat true; 7-very true } \\
\hline
\end{tabular}

Table 7. Self Esteem vs. Attitude of Employees

\begin{tabular}{|l|l|l|l|l|l|}
\hline & Mean & Standard Dev. & Pearson Chi & P Value & Decision \\
\hline Self-esteem & 5.23 & 1.41 & $.623^{*}$ & .003 & Significant \\
\cline { 1 - 3 } Attitude & 3.10 & .301 & & & \\
\hline
\end{tabular}

Like the hearing employers, the mean scores of the Deaf employees indicated high percentages in positive statements 1, 3, 4, 7, and 10, suggestive of high self-esteem. However, there was higher variability and distribution of scores compared with the previous frame of participants. Division of percentages between disagreement and agreement was highly evident on negative items 2,5, 6, and 9. There was also a high percentage of the score in statement 8 , which brings the issue of "selfrespect" into question.

W-BNS assessed the three components of psychological need satisfaction of the Deaf employees: autonomy, relatedness, and competence. The degree of agreement in the autonomy domain indicated variances in the perceived sense of control as indicated by their self-reliance, yet limited authority in the direction of their assigned tasks. In terms of competence, they recognized the opportunities given to them but stated that they could have achieved more. Lastly, in the 
relatedness domain, the participants agreed to a positive culture in their workplace but expressed their preference to work alone.

In an attempt to analyze how self-esteem mediates Deaf attitudes towards inclusion, a significant relationship was found statistically, implying that high self-esteem resulted in greater feelings of belonging and inclusion. In contrast, low self-esteem predicted a decreased sense of inclusion.

\section{Divergent Perspectives Between Hearing Employers and Deaf Employees}

Table 8. Hearing Employers vs Deaf Employees

\begin{tabular}{|l|l|l|l|l|l|}
\hline & Mean & $\begin{array}{l}\text { Standard } \\
\text { Dev. }\end{array}$ & Pearson Chi & P-Value & Decision \\
\hline Employers & 3.71 & .322 & 6.886 & .000 & Significant \\
\hline Employees & 5.23 & 1.41 & & & \\
\hline
\end{tabular}

A statistically significant difference between hearing employers' and Deaf employees' perspectives argued that absolute workplace inclusiveness is still non-existent. The employers' collective responses were indicative of high support for diversity, but the uncertainties on employees' responses raised questions on the sufficiency of available accommodations.

\section{Discussion}

\section{Seeing Through the Lens of Employers}

The study showed a predominance of positive regard towards the inclusion of Deaf in the current Philippine Metropolitan workforce. A point of convergence in the employers' statements revealed explicit support for diversity and favorable reception of Deaf integration. Generally, they perceive Deaf employees as potential assets, given their inherent attitudes and dedication towards work.

However, a significant discrepancy emerged with inherent assumptions, implying 'Deaf stigma' even up to date. Some employers, even if they have affirmative attitudes towards Deaf employment, still make assumptions about the limitations and capabilities of the Deaf. This mindset, in turn, may partly be explained by lack of experience, flawed understanding, and inadequate exposure to the Deaf community.

Analysis of employer responses gave rise to clusters and themes that further accentuate the gains, difficulties, and accommodations on Deaf employment.

The Irony of Perceived Weakness: Characterization of Deaf Employees from the Employer's Perspective

\section{Detachment from Audible Distractions}

Deaf employees are positively commended with their ability to focus on and strictly adhere to deadlines. Their acuity to small details is a common denominator that appeals to employers. Uncoupling from the workstation's noisy backdrops, given their hearing deficit, makes them externally impervious and exceptionally engaged in the task on hand.

\section{Dedication for Work Retention and Self-Worth}

One trait that makes Deaf employees stand out is their warmth and appreciation of their work, regardless of their position on the business ladder. They strive hard to prove themselves to their employers and everyone who tags them with unwarranted labels. Unlike typical hearing individuals who may be provided with more opportunities, they experience a longer waiting time to find the right jobs and inclusive companies. This misfortune makes them value the 'acceptance' they 
worked hard for; hence, they do everything to retain the position and give back to those who trusted them.

\section{Fulfillment of Corporate Social Responsibility}

Alongside the provision of opportunities on a skill-based approach, most employers consider Deaf employment as a means to embed "Corporate Social Responsibility" in their operations. Businesses that venture into hiring them assert that it is a contribution to the betterment of society. It then reflects the relevance of human rights in sustainable development by stipulating a workplace that promotes equal opportunity, regardless of differences. Furthermore, as hiring Deaf may serve as a platform to showcase diversity support, businesses become more appealing to potential clients and workers.

However, the involvement of enhanced corporate image with Deaf employment becomes controversial as it questions the real intention of Deaf integration. For that reason, employers tend to refute the idea and instead emphasize the quality of output and service that the Deaf can deliver.

\section{Expansion of Talent Pool}

In an economy where businesses struggle with skill shortages, Deaf employment offers an important proposition as Deaf individuals can also demonstrate an untapped breadth of viewpoints and experiences. They bring new knowledge to the table and help organizations see situations from different perspectives. Their adaptability to other conditions instigates out-of-thebox thinking and creative problem-solving. Additionally, Deaf employees tend to boost team harmony by having the team unite in recognizing collaborative understanding.

\section{Bridging the Gaps Towards Accessibility}

Despite the myriad reap of benefits and outward support on Deaf employment, employers still expressed reservations with some statements and opinions about the Deaf. Although they are empathic towards the Deaf, to some extent, they acknowledge the challenges of employing Deaf, with communication difficulties as the focal point. On top of this, the accommodation also infers an additional cost that should be shouldered by the company; hence, small businesses find it more difficult to adjust accordingly.

Typically, the recruitment process marks a crucial point as it requires additional effort in both parties. Employers verbalized that having an interpreter during job interviews is critical to clarify job descriptions and company policies' ambiguities. In Metro Manila, few organizations endeavor to assist the Deaf and employers through the 'match-making' process. Basically, they partner with the existing Deaf schools, match graduates with possible employers, and finally conduct Deaf awareness training. The foundation of these social enterprises, which started as initiatives, is substantial in advancing the status of the Deaf. Beyond interpreting services, they also offer job coaching and regular visits during the adjustment period, intending to bridge the communication gap between the hearing employer and the Deaf employee.

Employers, nonetheless, have different opinions on the role of these bridging organizations. Although the majority favor their holistic approach in integration, some companies still defer their full services as they would want their Deaf employees to be simply assimilated with other employees as much as possible. On top of additional cost issues, they intend to treat the Deaf employees just the same as the hearing employees; thus, the only accommodation they provide is interpretation service during interviews and training.

The speed and quality of communication are considered the top barriers of most employers, and to surmount these, non-spoken forms of communication are utilized. Interactions between Deaf workers and their hearing managers transpire through gestures, with occasional writing on 
notepads or texting sentences on mobile devices. Messages are conveyed primarily through email and text messages. Written communication, though, is deemed challenging as many Deaf do not have the same grammar as what the hearing individuals commonly use. In place of this, an adjustment may be necessary when transmitting a message across pen and paper and through email.

Concerning the health and safety of Deaf employees, one employer said they have a 'buddy system' protocol where a Deaf employee is partnered with a hearing employee in emergency cases. Another employer mentioned the use of lights synced with the alarm systems. The majority of companies, unfortunately, still lack measures to ensure safety precautions appropriate for the Deaf.

Driving is also an area which is believed to be a limitation of Deaf employees. Most employers expressed their doubts about hiring Deaf employees in positions that require driving. Due to their hearing impairment, it is presumed that their driving ability is also compromised, which, in turn, restricts work opportunities for the Deaf.

In terms of promotion and career advancement, doubts remain concerning the competencies and limitations of the Deaf community. Although employers could not articulate the rationale behind it, many still believe that there are limitations in position or roles offered to Deaf employees. Deaf employees rarely get promoted.

Augmenting the Voices of the Deaf Employees

Like any other job hunter, Deaf employees go through tedious recruitment, training, and adjustment at work. However, competition over employment with hearing individuals makes them more delayed in the transition to work. Although employers have evident optimism towards them, opportunities and positions remain inadequate.

The responses of the participating Deaf employees varied to extremes, with those who are exceedingly pleased with their work experience to those who vent frustration in their work. Dominantly, Deaf employees feel more than grateful for their jobs, and they work hard with hopes of advancement in the coming years. A few, though, have been in the same position overdue for promotion compared with hearing employees.

On the flipside, Deaf employees feel that many of their hearing counterparts are not that knowledgeable about the Deaf community. The medical or pathological perspective on deafness remains, and it pains the Deaf community. They want more people to see the Deaf from a sociocultural perspective, where deafness is viewed as a difference, not inferiority. They expressed their frustration in making people see that Deaf individuals use vision as a positive, efficient alternative to the auditory channel.

Furthermore, many of the Deaf participants conveyed their desire to show more of what they can do. They said that despite existent opportunities, work boundaries confine them in tasks that are simply within their comfort zones. Education was also raised as they know some Deaf friends who could be promising, but limited educational opportunities impede them from achieving their full potentials.

\section{Conclusion}

Much has been done to elevate the status of the Deaf, and significant changes are already existent in contemporary Philippine society. There is indeed a bright future for the Deaf Filipinos, as depicted by a growing number of companies and organizations where integration is thriving. Nevertheless, to be an entirely Deaf inclusive country, where stereotypes at work are thoroughly debunked, workplace accommodations still have a long way to go. Positive attitudes towards the 
Deaf have already sparked hope but combined with exposure and education, a chance of making a more significant difference awaits.

The answers to the thorny issue of full inclusion among the Deaf go beyond crude measures. Employer training is probably a good starting point to foster exposure with the Deaf, where modifications on organizational strategies can be based. Partnerships with organizations advocating the Deaf also provide valuable supplemental assistance. Furthermore, it is practical to promote the use of Filipino sign language in the Philippine educational system.

Collaborative efforts are indeed necessary to ensure success in Deaf integration. It may still take a while before full inclusiveness can be achieved, but all efforts will be worthwhile.

\section{Limitations}

\section{Limited Sample Size}

Although the sampling size was deemed suitable for mixed-method research, it was still not highly representative of the enormous Deaf community, given their heterogeneity. Due to the study's limitation, precise scope, and time constraints, the researcher purposively chose the participants who could provide valuable insights for interpretation. Most participants were college graduates, with only a few who had lower levels of education. A referral system was also utilized for the recruitment of participants. However, it should be noted that the researcher was well-informed on research ethics with samples of this nature.

\section{Consistency and Accuracy of Deaf Responses}

It was noted that Deaf participants utilized nonstandard grammatical forms of written language, as evident in their written responses. They demonstrated substantial variability in their writing with noticeable deficits in linguistic competence. Their written output displayed incoherent structures and confounding elements like fewer words, shorter clauses, lack of modifiers, and more errors than conventional English with limited to no access to the English language via acoustic input. In a nutshell, their writing could be described as rigid and straightforward.

This written composition of the Deaf was one of the most significant challenges that the researcher faced during data gathering. Only a few exhibited suitable grammatical structures, affecting their responses' consistency, accuracy, and clarity. Although their answers were understandable, to some extent, further elucidation was intricate. The researcher needed to decode their answers to yield commonalities and contrasting statements, and for some uncertainties, the assistance of a Deaf expert was sought.

Comprehension of the written questionnaires was also challenging because some Deaf participants would resort to inferencing for any confusing statements. With this, the researcher repeatedly asked the Deaf participants for any further clarification. The researcher warranted that participants were properly guided throughout their participation. For some participants, a Deaf expert also helped for interpretation.

\section{Social Desirability}

Congruent with literature, individuals are predisposed to constructing positive images as reflective of their interactions with minority groups, such as the Deaf. To a certain extent, employers may have been influenced by this tendency of social desirability by expressing positive regard towards Deaf employees and suppressing any negative comments.

On the part of the Deaf employees, they may have also wanted to show the researcher they were capable and had strong abilities, deemphasizing some of their challenges. 


\section{Suggestions for Future Research}

With the study's conclusion, the researcher recognized certain valuable areas of interest for future research. First, the researcher recommends adaptation with a modified approach to Deaf recruitment and a broader sampling scope. The researcher was able to consult with an expert in the field of Deaf integration, and she suggested translation of questionnaires into a Filipino Sign Language Format and conversion of output in the video. This technique addresses the dilemma of inconsistencies and probable inaccuracies in the results. A team will be comprised of a hearing Deaf expert and a Deaf individual. Tapping a broader and more diverse sector is also suggested to compare patterns in results and generate a more precise representation of various groups within the Deaf community.

Another area of concern is the educational opportunities for the Deaf in the Philippine setting, and this is crucial as the academic status of any individual positively affects the employment status. It is essential to investigate if the opportunities for the Deaf are adequate for them to acquire the same education with hearing peers. It is also highly recommended to review the literacy interventions provided with the Deaf and assess if they are optimal for them to express themselves in the written language. Likewise, it is also worthwhile to probe Filipino Sign Language implementation in different settings and examine the language constructs that may further be improved.

\section{References}

Baum, E. (2015). Discrimination against deaf and hard of hearing employees at work. Retrieved from https://www.eandblaw.com/deaf-law-centerblog/2015/12/04/discrimination-against-deafand-hard-of-hearing-employees-at-work.

Better Hearing Philippines, Inc. (2005). Prevalence of hearing impairment in the Philippines. Retrieved from https://www.bhphil.org/downloads/prevalence_of_ear.pdf.

Cooper, A., Rose, J. \& Mason, O. (2004). Measuring the attitudes of human service professionals toward deafness. American Annals of the Deaf, 148(5), 385-389.doi:10.1353/aad.2004.0001.

Deci, E. L., Ryan, R. M. (2000). The "what" and "why" of goal pursuits: Human needs and the selfdetermination of behavior. Psychological Inquiry, 11(4), 227-268.

Fraser, B. (2018). Cognitive disability aesthetics: Visual culture, disability representations, and the (in)visibility of cognitive difference. University of Toronto Press.

Friedner, M. (2013). Producing silent brewmasters: Deaf workers and added value in India's coffee cafés. Anthropology of Work Review, 34(1), 39-50. doi:10.1111/awr.12005.

Kemmery, M. A., \& Compton, M. V. (2014). Are you deaf or hard of hearing? Which do you go by: Perceptions of identity in families of students with hearing loss. Volta Review, 114(2), 157-192. doi:10.17955/tvr.114.2.748.

Lejzerowicz, M. (2016). Identity and its reconstruction and disabled people. International Journal on Disability and Human Development, 16(1), 19-24. doi:10.1515/ijdhd-2016-0036.

Nieweglowski, K. \& Sheehan, L. (2017). Relationship depth and associative stigma of disability. Disability Studies Quarterly, 37(3). doi:10.18061/dsq.v37i3.5527

Opoku, M., Mprah, W. \& Dogbe, J. \& Moitui, J. \& Badu, E. (2016). Access to employment in Kenya: The voices of persons with disabilities. International Journal on Disability and Human Development, 16(1), 77-87. doi:10.1515/ijdhd-2015-0029.

Perkins-Dock, R., Battle, T., Edgerton, J., \& McNeill, J. (2015). A survey of barriers to employment for individuals who are deaf. JADARA, 49(2). Retrieved from http://repository.wcsu.edu/jadara/vol49/iss2/3.

Powell-Williams, M. (2018). Life in neither world: Identity work as relational negotiation of authenticity and stigma management for biculturally deaf individuals living between worlds. Deviant Behavior, 39(2), 243-256. doi:10.1080/01639625.2016.1266890

Pranata, E., Latif, M. \& Fanani, F. (2019). Symbolic interaction of the deaf students in public school. Jurnal The Messenger, 11(1), 1-9. doi:10.26623/themessenger. v11i1.876. 
Ranada, P. (2018). New law orders gov't, schools, media to use Filipino sign language. Retrieved from https://www.rappler.com/technology/news/242782-netflix-3rd-quarter-2019-earnings-report.

Rosenberg, M. (1989). Society and the adolescent self-image. Revised edition. Middletown, CT: Wesleyan University Press.

Shuler, G., Mistler, L., Torrey, K., \& Depukat, R. (2014). More than signing: Communicating with the deaf. Nursing Management, 45(3), 20-27. doi:10.1097/01.NUMA.0000444299.04190.94

Silva-dela Cruz, F.W. \& Calimpusan, E. (2018). Status and challenges of the deaf in one City in the Philippines: towards the development of support systems and socio-economic opportunities. Asia Pacific Journal of Multidisciplinary Research, 6(2), 61-74. Retrieved from http://www.apjmr.com/wp-content/uploads/2018/02/APJMR-2017.6.2.09.pdf.

Stokar, H., \& Orwat, J. (2018). Hearing managers of deaf workers: A phenomenological investigation in the restaurant industry. American Annals of the Deaf, 163(1), 13-34. doi:10.1353/aad.2018.0009.

Turcotte, M. (2014). Persons with disabilities and employment. Retrieved from https://www.academia.edu/33074513/Persons_with_disabilities_and_employment.

United Nations Department of Economic and Social Affairs (2018). Disability and development report: Realizing the sustainable development goals by, for, and with persons with disabilities. Retrieved from https://www.un.org/development/desa/disabilities/wpcontent/uploads/sites/15/2018/12/UN-Flagship-Report-Disability.pdf.

Waldschmidt, A., Berressem, H., \& Ingwersen, M. (Eds.). (2017). Culture - theory - disability: Encounters between disability studies and cultural studies. Bielefeld: Transcript Verlag. Retrieved from http://www.jstor.org/stable/j.ctv1xxs3r.

West, J., Low, J. \& Stankovic, K. (2015). Revealing hearing loss: A survey of how people verbally disclose their hearing loss. Ear and Hearing. 37(2), 194-205. doi:10.1097/AUD.0000000000000238.

Wong, A. (2016). Escaping the disability trap. Retrieved from https://www.theatlantic.com/ education/archive/2016/06/escaping-the-disability-trap/487070.

World Health Organization. (2019). Fact sheet: Deafness and hearing loss. Retrieved from https://www.who.int/news-room/fact-sheets/detail/deafness-and-hearing-loss. 


\title{
Redefining Social Constructs: An Exploratory Research on the Integration of Deaf Employees in the Philippine Metropolitan Workforce
}

\author{
Janine Sagala, MClAud \\ University of Santo Tomas, Philippines \\ janine.sagala.med@ust.edu.ph|jpssagala.ust@gmail.com
}

\author{
Appendix I: Cover Letter \\ Appendix II: Consent Forms \\ Appendix III: Demographic Questionnaire \\ Appendix IV: Attitude to Deafness Scale \\ Appendix V: Rosenberg Self Esteem Scale. \\ Appendix VI: Basic Need Satisfaction Scale at Work \\ Appendix VII: Interview Guide. \\ Appendix VIII: Research Instruments' Permission to Use. \\ Appendix IX: Certificate of Good Clinical Practice \\ Appendix X: Technical Review and Ethics Review Certificates \\ Appendix XI: Results: Tabular Data
}


APPENDIX I:

Cover Letter 


\section{Dear Participant,}

Greetings in the name of St. Thomas Aquinas!

My name is Janine Sagala, a graduate student from the University of Sto. Tomas Faculty of Medicine and Surgery Clinical Audiology Program, and I am conducting a research exploring the inclusiveness of Philippine Metropolitan workforce in Deaf employment.

The study aims to systematically investigate on employer attitudes, accommodations, struggles and achievements in the employment of Deaf employees, while taking into account the real essence of workplace inclusion in the companies situated in Metro Manila. It is the objective of the study to understand the relationship between the perspectives of both employers and employees regarding the issue of inclusion, with the hope of improving inclusion strategies within organizations.

Furthermore, since studies about the position of Deaf remain scarce, despite the growing prevalence of deafness in the country, the data to be collected endeavors to be an insightful groundwork from which further studies can be conducted.

In this regard, you are invited to take part in this study and participation requires completing the attached survey. Participation is completely voluntary and thus, you are not obliged to take part. It is also anonymous and confidential. Hence, responses cannot be attributed to any of the participants.

The questionnaires will be securely stored, and data will be consolidated in an electronic format on a password protected computer.

By completing the questionnaire, you are consenting to participate in the study.

Should you require further information, you may contact me at 09354419048 or jpssagala@gmail.com.

Regards,

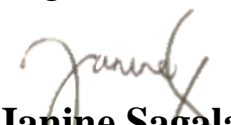

Janine Sagala

Audiology Student

Date: 09 October 2019 
APPENDIX II:

Consent Forms 
Faculty of Medicine and Surgery

Department of Otorhinolaryngology

Center for Audiological Sciences

\section{Title of the research:}

Redefining Social Constructs: An Exploratory Research on the Integration of Deaf Employees in the Philippine Workforce

$\mathrm{I}$, of this research. , without coercion or force, freely and voluntarily consent to be part

It is clear to me that the rationale of this study is to gain information about the status of the Deaf community in the Philippine workforce. As part of this study, I will be asked to respond about my attitudes towards hiring Deaf employees, personal opinions and general demographics about myself.

I understand that my participation is voluntary, and I may stop participating at any time. In agreeing to participate, I acknowledge that I am at least (18) years of age. My name will not appear on any of the results and only group findings will be reported. Information to be obtained during the study will remain confidential, to the extent allowed by law.

I understand that there may be minimal risk associated with the participation in this study due to anxiety with reporting my genuine attitudes towards the Deaf people. With this, I have the option of withdrawing my participation at any time, without penalty or prejudice. The researcher will also guide me with my engagement.

Results from the study may be sent to me upon request.

Signature of Participant

Date

Signature of Researcher

Date 


\section{Title of the research:}

Redefining Social Constructs: An Exploratory Research on the Integration of Deaf Employees in the Philippine Metropolitan Workforce

$\mathrm{I}$, without coercion or force, freely and voluntarily consent to be part of this research.

It is clear to me that the rationale of this study is to gain information about the status of the Deaf community in the Philippine workforce. As part of this study, I will be asked to respond about my feelings toward my company's inclusion strategies, personal opinions and general demographics about myself.

I understand that my participation is voluntary, and I may stop participating at any time. In agreeing to participate, I acknowledge that I am at least (18) years of age. My name will not appear on any of the results and only group findings will be reported. Information to be obtained during the study will remain confidential, to the extent allowed by law.

I understand that there may be minimal risk associated with the participation in this study due to anxiety with reporting my genuine attitudes towards my employer. With this, I have the option of withdrawing my participation at any time, without penalty or prejudice. The researcher will also guide me with my engagement.

Results from the study may be sent to me upon request.

Signature of Participant

Date

Signature of Researcher

Date 
APPENDIX III:

Demographic Questionnaire 
DEMOGRAPHIC QUESTIONNAIRE - EMPLOYER

Please be assured that the answers you give will be kept confidential.

\begin{tabular}{|c|c|c|c|}
\hline \multicolumn{2}{|l|}{$\begin{array}{l}\text { 1. Age: } \\
\square \text { 18-29 years } \\
\square \text { 30-41 years } \\
\square 42-53 \text { years } \\
\square 65 \text { and older }\end{array}$} & \multicolumn{2}{|l|}{$\begin{array}{l}\text { 2. Sex: } \\
\square \text { Male } \\
\square \text { Female }\end{array}$} \\
\hline \multicolumn{2}{|c|}{$\begin{array}{l}\text { 3. Education: What is the highest level of } \\
\text { education you completed? } \\
\square \text { High school or equivalent } \\
\square \text { Certificate or training program } \\
\square \text { Bachelors } \\
\square \text { Masters } \\
\square \text { Doctorate } \\
\square \text { Other: }\end{array}$} & $\begin{array}{l}\square \text { HR Prof } \\
\square \text { Manage } \\
\square \text { Executi } \\
\text { Other: }\end{array}$ & $\begin{array}{l}\text { hal } \\
\text { apervisor } \\
\text { ner }\end{array}$ \\
\hline $\begin{array}{l}\text { 5. How long have you been worl } \\
\text { current organization? } \\
\square \quad \text { Less than } 1 \text { year } \\
\square \quad 1-3 \text { years } \\
\square \quad 4-6 \text { years } \\
\square \quad 7 \text { - } 10 \text { years } \\
\square \quad \text { More than } 10 \text { years }\end{array}$ & king with your & $\begin{array}{l}\text { 6. Have yo } \\
\text { employee? } \\
\square \text { Yes } \\
\square \text { No }\end{array}$ & r employed a signing Deaf \\
\hline \multicolumn{4}{|c|}{ 7. Which of the following categories best describes the industry you primarily work in? } \\
\hline $\begin{array}{l}\square \text { Agriculture, Forestry and Fishing } \\
\square \text { Mining and quarrying } \\
\square \text { Manufacturing } \\
\square \text { Electricity, gas, steam and air } \\
\text { conditioning supply } \\
\square \text { Water supply, sewerage, waste } \\
\text { management and remediation } \\
\text { activities } \\
\square \text { Construction } \\
\square \text { Wholesale and retail trade; } \\
\text { repair of motor vehicles and } \\
\text { motorcycles } \\
\square \text { Transportation and storage }\end{array}$ & $\begin{array}{l}\square \text { Accommodat } \\
\text { service activities } \\
\square \text { Information a } \\
\text { Communication } \\
\square \text { Financial and } \\
\text { activities } \\
\square \text { Real estate ac } \\
\square \text { Professional, } \\
\text { technical service } \\
\square \text { Administrativ } \\
\text { service activities } \\
\square \text { Public admini } \\
\text { defense; compul } \\
\text { security }\end{array}$ & $\begin{array}{l}\text { In and food } \\
\text { nsurance } \\
\text { vities } \\
\text { cientific and } \\
\text { and support } \\
\text { trative and } \\
\text { ory social }\end{array}$ & $\begin{array}{l}\square \text { Education } \\
\square \text { Human health and social work } \\
\text { activities } \\
\square \text { Arts, entertainment and } \\
\text { recreation } \\
\square \text { Other service activities } \\
\square \text { Activities of private households } \\
\square \text { Activities of extraterritorial } \\
\text { organizations and bodies }\end{array}$ \\
\hline
\end{tabular}


DEMOGRAPHIC QUESTIONNAIRE - EMPLOYEE

Please be assured that the answers you give will be kept confidential.

\begin{tabular}{|c|c|c|c|}
\hline \multicolumn{2}{|l|}{$\begin{array}{l}\text { 1. Age: } \\
\square \text { 18-29 years } \\
\square 30-41 \text { years } \\
\square 42-53 \text { years } \\
\square 65 \text { and older }\end{array}$} & \multicolumn{2}{|l|}{$\begin{array}{l}\text { 2. Sex: } \\
\square \text { Male } \\
\square \text { Female }\end{array}$} \\
\hline \multicolumn{2}{|c|}{$\begin{array}{l}\text { 3. Education: What is the highest level of } \\
\text { education you completed? } \\
\square \text { High school or equivalent } \\
\square \text { Certificate or training program } \\
\square \text { Bachelors } \\
\square \text { Masters } \\
\square \text { Doctorate } \\
\square \text { Other: }\end{array}$} & \multicolumn{2}{|c|}{$\begin{array}{l}\text { 4. Which of the following best describes your } \\
\text { current role in the organization? } \\
\square \text { Production/Service Staff } \\
\square \text { Professional } \\
\square \text { Manager or Supervisor } \\
\square \text { Executive/Partner } \\
\text { Other: }\end{array}$} \\
\hline \multicolumn{2}{|c|}{$\begin{array}{ll}\square & \text { Less than } 1 \text { year } \\
\square & 1-3 \text { years } \\
\square & 4-6 \text { years } \\
\square & 7-10 \text { years } \\
\square & \text { More than } 10 \text { years }\end{array}$} & $\begin{array}{l}\square \text { Full time } \\
\square \text { Part time } \\
\square \text { Project-I }\end{array}$ & 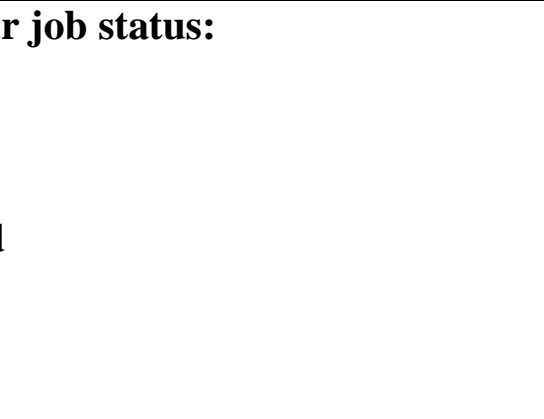 \\
\hline \multicolumn{4}{|c|}{ 7. Which of the following categories best describes the industry you primarily work in? } \\
\hline $\begin{array}{l}\square \text { Agriculture, Forestry and Fishing } \\
\square \text { Mining and quarrying } \\
\square \text { Manufacturing } \\
\square \text { Electricity, gas, steam and air } \\
\text { conditioning supply } \\
\square \text { Water supply, sewerage, waste } \\
\text { management and remediation } \\
\text { activities } \\
\square \text { Construction } \\
\square \text { Wholesale and retail trade; } \\
\text { repair of motor vehicles and } \\
\text { motorcycles } \\
\square \text { Transportation and storage }\end{array}$ & \multicolumn{2}{|c|}{$\begin{array}{l}\square \text { Accommodation and food } \\
\text { service activities } \\
\square \text { Information and } \\
\text { Communication } \\
\square \text { Financial and insurance } \\
\text { activities } \\
\square \text { Real estate activities } \\
\square \text { Professional, scientific and } \\
\text { technical services } \\
\square \text { Administrative and support } \\
\text { service activities } \\
\square \text { Public administrative and } \\
\text { defense; compulsory social } \\
\text { security }\end{array}$} & $\begin{array}{l}\square \text { Education } \\
\square \text { Human health and social work } \\
\text { activities } \\
\square \text { Arts, entertainment and } \\
\text { recreation } \\
\square \text { Other service activities } \\
\square \text { Activities of private households } \\
\square \text { Activities of extraterritorial } \\
\text { organizations and bodies }\end{array}$ \\
\hline
\end{tabular}




\section{APPENDIX IV:}

Attitude to Deafness Scale 


\section{Attitude to Deafness Scale}

No.

Please answer the following questions on a scale of 1-6.

1. Deaf couples should receive genetic counselling to avoid having deaf children.

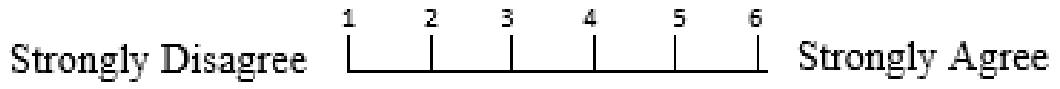

2. Deaf children should learn to speak to communicate with hearing parents.

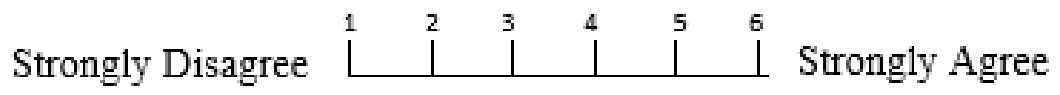

3. I would like to have more deaf friends.

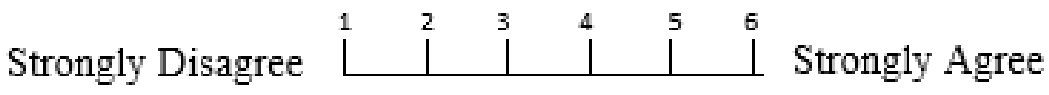

4. Deaf schools and deaf clubs create deaf 'ghettos'.

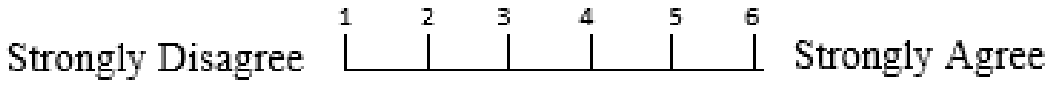

5. Deaf people should learn speech rather than sign language.

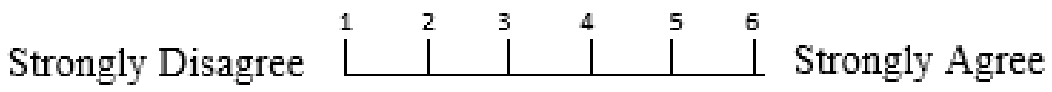

6. Deaf people are handicapped.

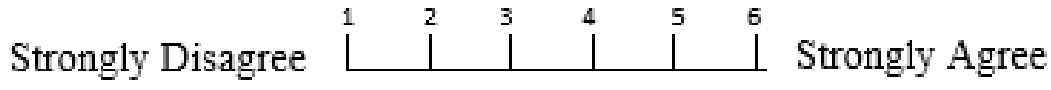

7. More research should be done to find cures for deafness.

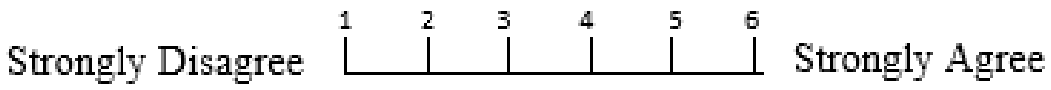

8. Deaf children should be taught in sign language.

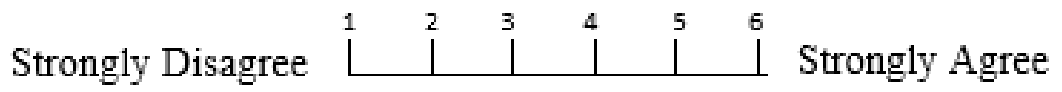

9. Hearing children of deaf parents are at risk of emotional deprivation.

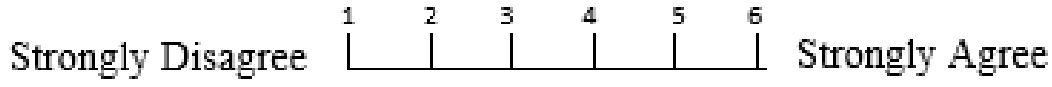

10. Deaf people are safe drivers.

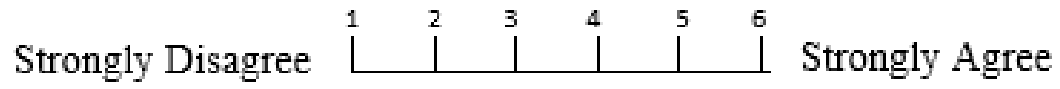

11. I would like to have more deaf colleagues.

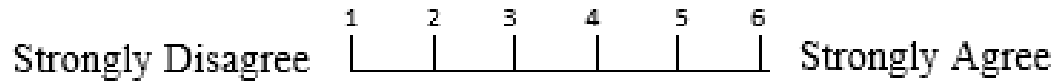


12. Deaf people should learn to lip read.

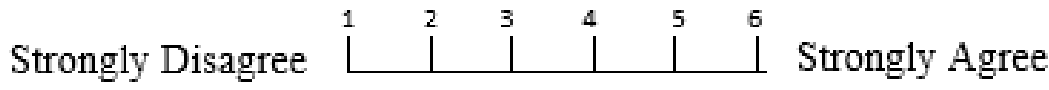

13. Interpreters should be available for deaf people at work.

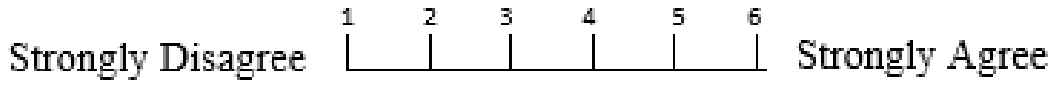

14. Deaf people should automatically receive help in their home environment.

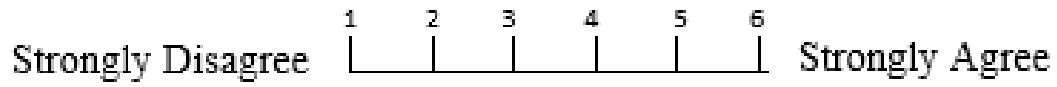

15. All deaf people should be offered corrective surgerv.

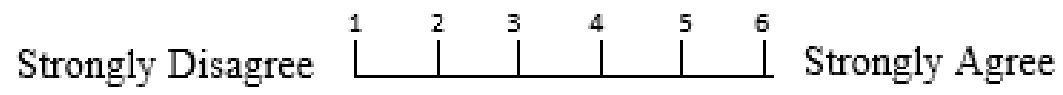

16. Training more mental health professionals to work with deaf clients would be a waste of time.

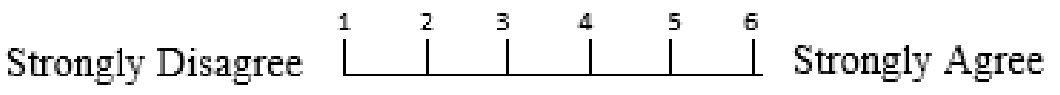

17. Having a deaf colleague would cause problems in the work place.

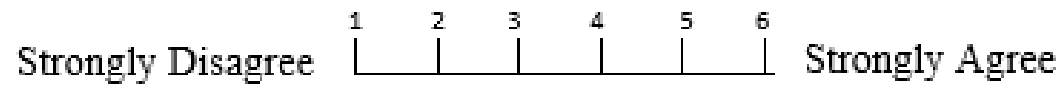

18. Deaf people are physiologically impaired.

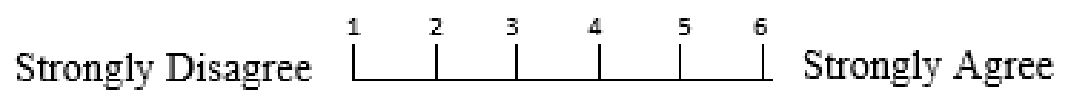

19. Deaf people should not be viewed as "impaired."

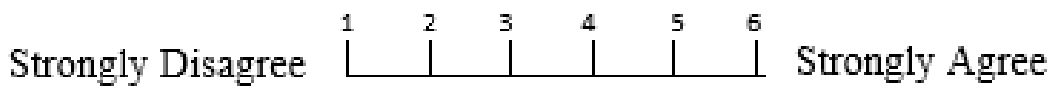

20. I would like to see more deaf people at the clubs/societies I attend.

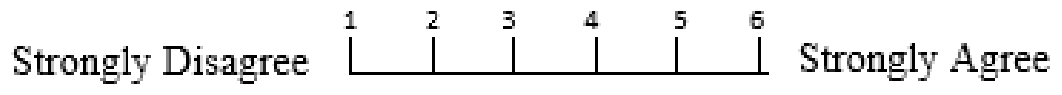

21. Having a deaf friend would be difficult.

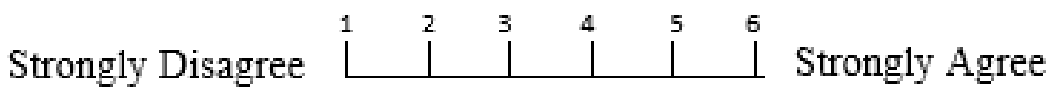

22. Deaf people have their own culture.

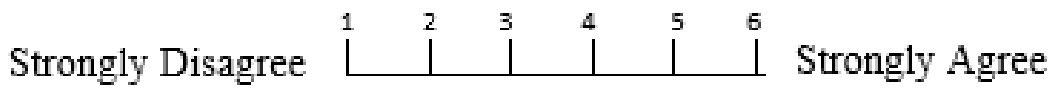


APPENDIX V:

Rosenberg Self Esteem Scale 
Rosenberg Self Esteem Scale (Rosenberg, 1965)

No.

Below is a list of statements dealing with your general feelings about yourself.

If you strongly agree with the statement circle SA.

If you agree with the statement circle A.

If you disagree with the statement circle D.

If you strongly disagree with the statement circle SD.

\begin{tabular}{|c|c|c|c|c|c|}
\hline 1. & On the whole, I am satisfied with myself. & SA & A & D & SD \\
\hline 2. & At times, I think I am no good at all. & SA & A & D & SD \\
\hline 3. & I feel that I have a number of good qualities. & SA & A & D & SD \\
\hline 4. & I am able to do things as well as most other people. & SA & A & D & SD \\
\hline 5. & I feel I do not have much to be proud of. & SA & A & D & SD \\
\hline 6. & I certainly feel useless at times. & SA & A & D & SD \\
\hline 7. & $\begin{array}{l}\text { I feel that I'm a person of worth, at least on an equal plane with } \\
\text { others. }\end{array}$ & SA & A & D & SD \\
\hline 8. & I wish I could have more respect for myself. & SA & A & D & SD \\
\hline 9. & All in all, I am inclined to feel that I am a failure. & SA & A & D & SD \\
\hline 10. & I take a positive attitude toward myself. & SA & A & D & SD \\
\hline
\end{tabular}


APPENDIX VI:

Basic Need Satisfaction Scale at Work 
Basic Need Satisfaction at Work

No.

(When I am at work)

The following questions concern your feelings about your job during the last year. (If you have been on this job for less than a year, this concerns the entire time you have been at this job.) Please indicate how true each of the following statement is for you given your experiences on this job. Remember that your boss will never know how you responded to the questions. Please use the following scale in responding to the item.

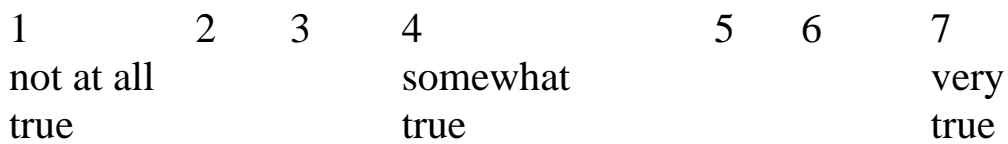

1. I feel like I can make a lot of inputs to deciding how my job gets done.

2. I really like the people I work with.

3. I do not feel very competent when I am at work.

4. People at work tell me I am good at what I do.

5. I feel pressured at work.

6. I get along with people at work.

7. I pretty much keep to myself when I am at work.

8. I I fm free to express my ideas and opinions on the job.

9. I consider the people I work with to be my friends.

10. I have been able to learn interesting new skills on my job.

11. When I am at work, I have to do what I am told.

12. Most days I feel a sense of accomplishment from working.

13. My feelings are taken into consideration at work.

14. On my job I do not get much of a chance to show how capable I am.

15. People at work care about me.

16. There are not many people at work that I am close to.

17. I feel like I can pretty much be myself at work.

18. The people I work with do not seem to like me much.

19. When I am working, I often do not feel very capable.

20. There is not much opportunity for me to decide for myself how to go about my work.

21. People at work are pretty friendly towards me. 
APPENDIX VII:

Interview Questions 


\section{INTERVIEW GUIDE - EMPLOYER}

1. Describe your understanding of diverse and inclusive workplace. Do you think it is important? Why?

2. Are the company's recruiting efforts supporting a diverse culture?

3. Can you share data on your organization's diversity? Have you ever had a signing Deaf employee?

4. What are your perceived difficulties and gains on Deaf employment?

5. What kind of accommodations do you provide for your Deaf employees?

6. Do you think Deaf employees can be assets to your organization?

\section{INTERVIEW GUIDE - EMPLOYEE}

1. Have you encountered difficulties in your career that are not experienced by all of your colleagues? Describe them.

2. Describe your experience in your company's recruitment process.

3. Do you feel that you have sufficient support to develop your skills and progress your career?

4. What are the accommodations being provided by your organization? Can you think of any accommodation that your company needs to improve on?

5. How do you see your working progress in the coming five years? 
APPENDIX VIII:

Research Instruments'

Permission to Use 


\title{
Requesting Permission to use Rosenberg Self Esteem Scale
}

\author{
Thank you for your submission. You now have permission to use the Rosenberg Scale. \\ Please be sure to properly cite Dr. Rosenberg's work in your paper or project. The most \\ appropriate citation is: 'Rosenberg, Morris. 1989. Society and the Adolescent Self-Image. \\ Revised edition. Middletown, CT: Wesleyan University Press". \\ Edit your response
}

Research on Self-Determination Theory has included laboratory experiments and field studies in several different settings. In order to do this research, we have developed many questionnaires to assess different constructs contained within the theory. Each questionnaire page will typically include:

- the scale

- description of the scale

- a key for the scale, and

- references for articles describing studies that used the scale

*** Please note that all questionnaires on this web site, developed for research on selfdetermination theory, are copyrighted. You are welcome to use the instruments for academic (noncommercial) research projects. However, you may not use any of them for any commercial purposes without written permission to do so from the Center for Self-Determination Theory. To inquire about a commercial requests, please email: shannon@selfdetermationtheory.org

Click on any questionnaire name below to access the scale or set of questionnaires and other information.

\section{Aspirations Index}

\section{Basic Psychological Need Satisfaction, and Frustration Scales}

\section{General Causality Orientations Scale - Studies}


RE: ?spam? Permission to Use: Attitudes to Deafness Scale Inbox $\times$

John Rose

르, Mct 7, 1:34 AM (2 days ago)

to me $\mathrm{r}$

Hello Janine,

Yes, that's fine please feel free to use the measure, it may need some adaptation.

I attach a copy for you.

Good luck with your research.

John Rose

From: janine.sagala.med@ust.edu.ph [mailto:janine.sagala.med@ust.edu.ph]

Sent: 05 October 2019 10:16

To: John Rose (Psychology)

Subject: ?spam? Permission to Use: Attitudes to Deafness Scale

Dear Mr. Rose,

Good day!

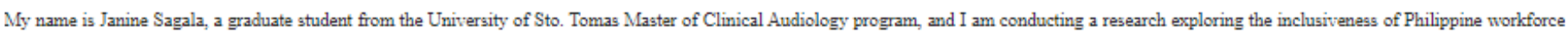
in deaf employment.

In my study, I would like to systematically investigate on employer attitudes, accommodations, struggles and achievements in the employment of deaf employees, while taking into account the real essence of workplace inclusion.

Since studies about the position of deaf employees in the workplace remain scarce, despite the growing prevalence of deafness in the Philippines, the data to be collected endeavors to be an insightful groundwork from which further studies can be conducted. It also intends to instigate programs that may still be missing to consider the country as being 'inclusive'.

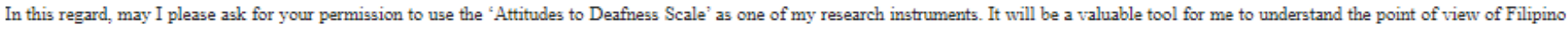
employers.

If you have any questions, please let me know.

Thank you so much.

Regards,

Janine Sagala 
APPENDIX IX:

Certificate of Good

Clinical Practice 


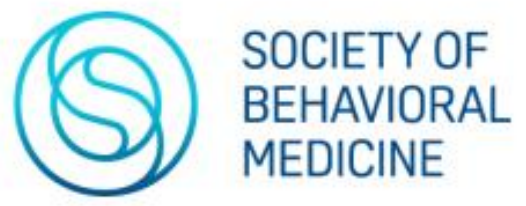

Good Clinical Practice Training for Social and Behavioral Research

CERTIFICATE of COMPLETION

\author{
This certifies that \\ Janine P. Sagala \\ SBM tracking ID: 29865 \\ completed the National Institutes of Health Office of Behavioral and Social Science Research good clinical practice for social and \\ behavioral research in clinical trials e-learning course on 10/19/2019.
}

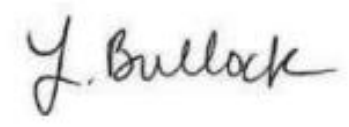

Lindsay Bullock

Executive Director, Society of Behavioral Medicine

Society of Behavioral Medicine

555 East Wells Street, Suite 1100 * Milwaukee, WI * 53202

Phone: (414) 918-3156 * Fax: (414) 276-3349

www.sbm.org 
APPENDIX X:

Technical Review

Committee and Ethics

Review Committee

Certificates 

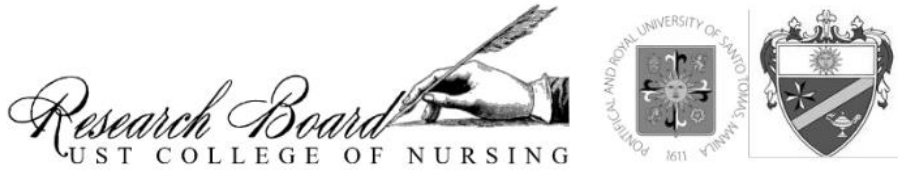

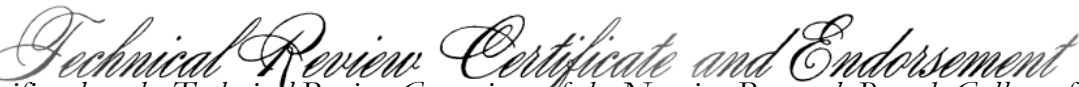

This certifies that the Technicat Review Committee of the Nursing Research Board, College of Nursing, University of Santo Tomas has critically reviewed the technical merit of the research protocol indicated below following the institutional by-laws and policies in research of the College of Nursing:

\begin{tabular}{|l|l|}
\hline Protocol Title: & $\begin{array}{l}\text { Redefining Social Constructs: An Exploratory Research on the } \\
\text { Integration of Deaf Employees in the Philippine Metropolitan } \\
\text { Workforce }\end{array}$ \\
\hline Protocol Version \& Date: & Protocol Version 1 as of [ November 6, 2019] \\
\hline Research Investigator(s): & Janine Sagala \\
\hline Institutional Affiliation: & $\begin{array}{l}\text { University of Santo Tomas, Faculty of Medicine and Surgery, } \\
\text { Clinical Audiology }\end{array}$ \\
\hline
\end{tabular}

The Technical Review Committee confirms that the foundational, argumentative, procedural and empirical dimensions of the

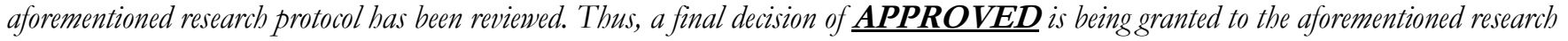
and will be implemented under the oversight of the Nursing Research Board and College of Nursing in accordance with the conditions of ethical approval from the UST Nursing Ethics Research Review Committee (NERRC).

\section{Endorsed by:}

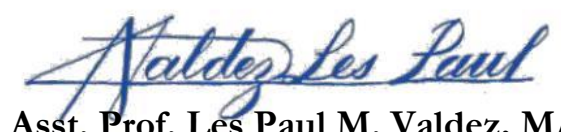

\section{Asst. Prof. Les Paul M. Valdez, MAN RN}

Chair, Nursing Research Board

Date: 11| 6 | 2019

\section{Received by:}

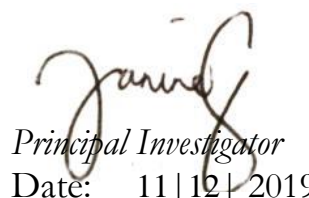


USTCON ERC Form 4.C: Approval Letter of Study Protocol Submission

01 August 2017 Version 1

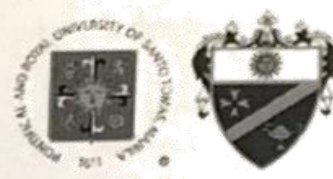

\section{UST COLLEGE OF NURSING}

ETHICS REVIEW COMMITTEE

1: Floor Room 105, St. Martin de Porres Building. España, Manila, Philippines 1015

Telephone: (632) 406-1611 local 8362 | (632) $731-5738$

Email: erc-nursing a ust.edu.ph

11 January 2020

JANINE P. SAGALA

Principal Investigator

University of Santo Tomas

Faculty of Medicine and Surgery

St. Martin de Porres Building, España, Manila,

\section{RE USTCON-2020-OR05 \\ REDEFINING SOCIAL CONSTRUCTS: AN EXPLORATORY RESEARCH ON THE INTEGRATION OF DEAF EMPLOYEES IN THE PHILIPPINE METROPOLITAN WORKFORCE}

Dear Ms. Sagala:

Greetings in the name of St. Thomas Aquinas!

We wish to inform you that your study protocol entitled, REDEFINING SOCIAL CONSTRUCTS: AN EXPLORATORY RESEARCH ON THE INTEGRATION OF DEAF EMPLOYEES IN THE PHILIPPINE METROPOLITAN WORKFORCE with a protocol code of USTCON-2020-OR05, has been reviewed by the UST College of Nursing Ethics Review Board and has been APPROVED for implementation.

The following study-related documents have been reviewed and approved for use in the study:

1. Study Protocol Version 1 dated November 18, 2019;

2. Informed Consent Form Version 1 dated 18 November 2019;

3. Research Tools: Appendix III: Demographic Questionnaire Employer and Employee; Appendix IV: Attitude to Deafness Scale; Appendix V: Rosenberg Self-Esteem Scale; Appendix VI: Basic Need Satisfaction Scale at Work; Appendix VII: Interview Guide Questions

4. Curriculum Vitae of Sagala, Janine P., (Principal Investigator);

5. Basic Research Ethics Training and Good Clinical Practice Workshop Certificate completed October 19, 2019 Society of Behavioral Medicine

The USTCON Ethics Review Committee also reminds the researcher for his/her responsibilities upon approval of this study protocol: 
USTCON ERC Form 4.C: Approval Letter of Study Protocol Submission

01 August 2017 Version 1

1. Submit any amendment(s) in the approved study protocol or other study-related documents (i.e., informed consent form, assent form, etc.) using USTCON ERC Form 3.A: Study Protocol Amendment Form;

2. Submit a progress report every 6 months using the USTCON ERC Form 3.B: Continuing Review Application Form;

3. Report any adverse events, including those from other study sites, using USTCON ERC Form 3.F: Serious Adverse Event Report Form with the timeline of submission as follows:

a. On-site and local SAEs: Within $24-48$ Hours from occurrence

b. Onsite and local SUSARs: Within 7 days from occurrence

c. International/Foreign SAEs and SUSARs: Within 14 days

d. Non-serious adverse reactions: Within 14 days

4. Apply for early study protocol termination and the reason for such using USTCON ERC Form 3.E: Study Termination Application Form;

5. Report any non-compliance, violation, or deviation from the approved study protocol using USTCON ERC Form 3.D: Study Non-Compliance Form within seven (7) days;

6. Notify the USTCON ERC for any event which may have ethical relevance and may be needed by the committee to conduct on-going review;

7. Adhere to all relevant national and international ethical guidelines and policies; and,

8. Submit a final report of the completed study using USTCON ERC Form 3.C: Final Report Form.

The ethical clearance for the abovementioned study protocol is until 11 January 2021 (Mondav). The application for renewal of ethical clearance must be submitted 90 days before the expiration data using USTCON ERC Form USTCON ERC Form 3.B: Continuing Review Application Form.

Please note that all relevant forms may be requested from the USTCON ERC Secretary whom you may contact at (632) 406-1611 local 8362 or at erc-nursing@ust.edu.ph.

Thank you and God bless!

Respectfully,

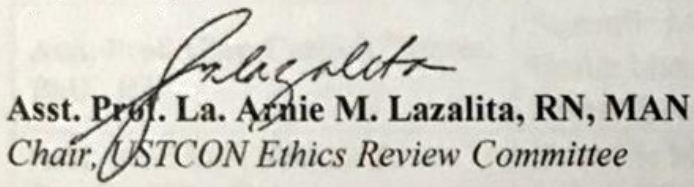

UST: A012-00-FO112 
STCON ERC Form 4.C: Approval Letter of Study Protocol Submission 01 August 2017 Version 1

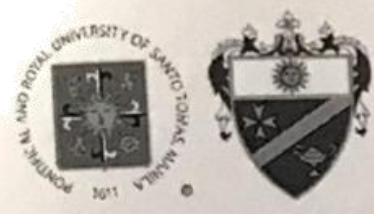

\section{UST COLLEGE OF NURSING} ETHICS REVIEW COMMITTEE

$1^{\text {st }}$ Floor Room 105, St. Martin de Porres Building, España, Manila, Philippines 1015 Telephone: (632) 406-1611 local 8362 | (632) 731-5738

Email: erc-nursing@ust.edu.ph

\section{Committee Composition}

\begin{tabular}{|l|l|}
\hline Protocol Code & $:$ USTCON-2020-OR05 \\
\hline Protocol Title & $\begin{array}{l}\text { REDEFINING SOCIAL CONSTRUCTS: AN EXPLORATORY } \\
\text { RESEARCH ON THE INTEGRATION OF DEAF } \\
\text { EMPLOYEES IN THE PHILIPPINE METROPOLITAN } \\
\text { WORKFORCE }\end{array}$ \\
\hline Principal Investigator & $:$ Janine P. Sagala \\
\hline Affiliation & $:$ University of Santo Tomas Faculty of Medicine and Surgery \\
\hline Date of Approval & $:$ January 11, 2020 \\
\hline
\end{tabular}

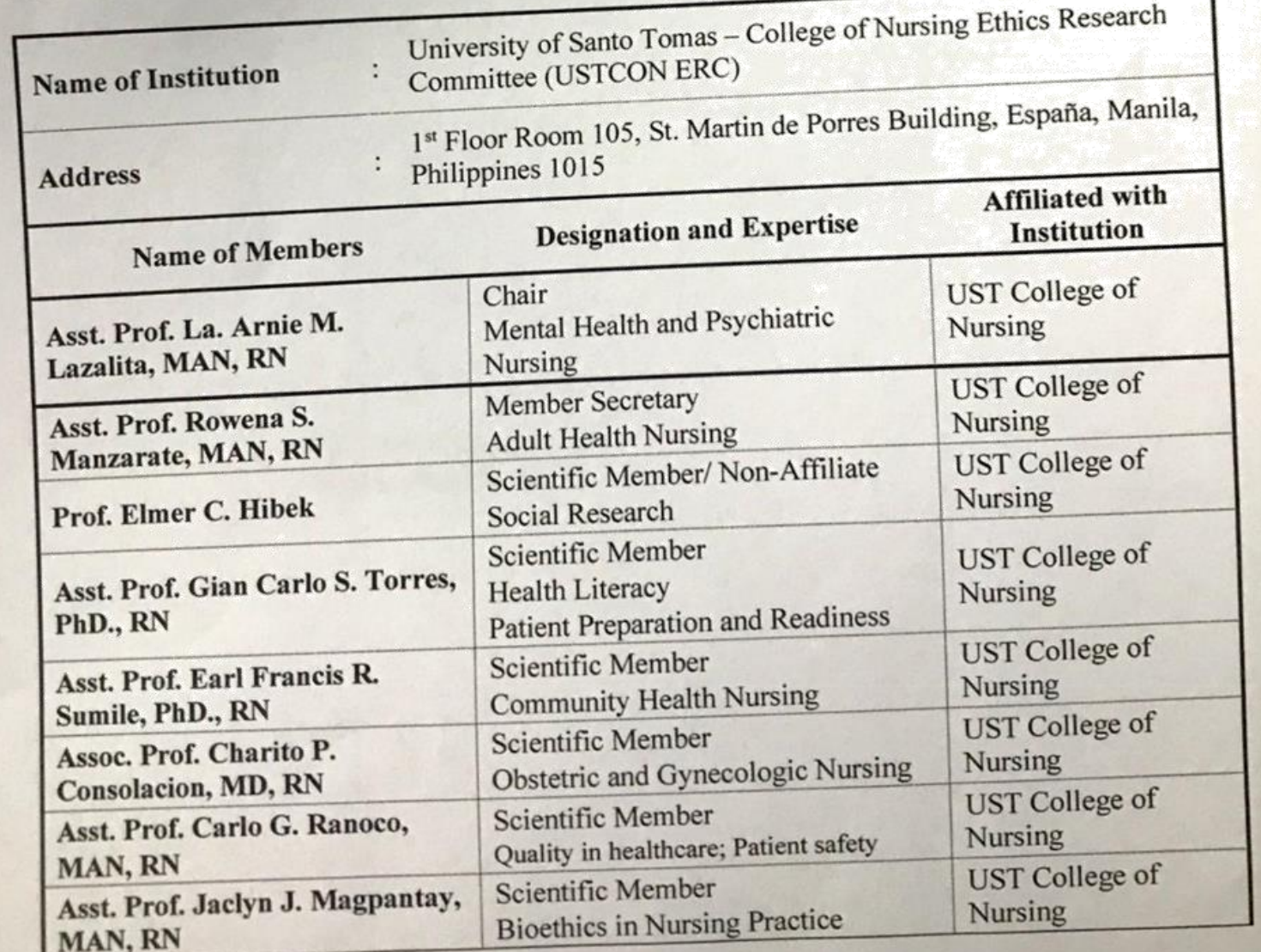




\section{APPENDIX XI:}

RESULTS: TABULAR DATA 
DEMOGRAPHIC RESULTS: EMPLOYERS

\begin{tabular}{|c|c|c|c|c|c|c|c|}
\hline \multicolumn{2}{r}{ Age } & \multicolumn{1}{c}{ Sex } & Education & \multicolumn{1}{c}{ Position } & \multicolumn{1}{c|}{ Experience } & \multicolumn{1}{c|}{ Deaf Exp } & Industry \\
\hline Valid & 66 & 69 & 69 & 67 & 69 & 68 & 69 \\
\hline Missing & 24 & 21 & 21 & 23 & 21 & 22 & 21 \\
\hline
\end{tabular}

\section{FREQUENCY TABLES}

\begin{tabular}{|l|l|l|l|l|l|}
\hline AGE & Frequency & Percent & Valid \% & Cumulative \% \\
\hline \multirow{4}{*}{ Valid } & $18-29$ & 32 & 35.6 & 48.5 & 48.5 \\
\cline { 2 - 6 } & $30-41$ & 28 & 31.1 & 42.4 & 90.9 \\
\cline { 2 - 6 } & $42-53$ & 6 & 6.7 & 9.1 & 100 \\
\cline { 2 - 6 } & Total & 66 & 73.3 & 100 & \\
\hline Missing & System & 24 & 26.7 & & \\
\hline \multicolumn{2}{|l|}{ Total } & 90 & 100 & & \\
\hline
\end{tabular}

\begin{tabular}{|l|l|l|l|l|l|}
\hline SEX & Frequency & Percent & Valid \% & Cumulative \% \\
\hline \multirow{3}{*}{ Valid } & Female & 47 & 52.2 & 68.1 & 68.1 \\
\cline { 2 - 6 } & Male & 22 & 24.4 & 31.9 & 100 \\
\cline { 2 - 6 } & Total & 69 & 76.7 & 100 & \\
\hline Missing & System & 21 & 23.3 & & \\
\hline Total & 90 & 100 & & \\
\hline
\end{tabular}

\begin{tabular}{|l|l|l|l|l|l|}
\hline EDUCATIONAL BACKGROUND & Frequency & Percent & Valid \% & Cumulative \% \\
\hline Valid & bachelors & 54 & 60.0 & 78.3 & 78.3 \\
\hline & masters & 13 & 14.4 & 18.8 & 97.1 \\
\hline & high school or equivalent & 1 & 1.1 & 1.4 & 100 \\
\hline & training program & 1 & 1.1 & 1.4 & 98.6 \\
\hline & Total & 69 & 76.7 & 100 & \\
\hline Missing & System & 21 & 23.3 & & \\
\hline Total & 90 & 100 & & \\
\hline
\end{tabular}

\begin{tabular}{|l|l|l|l|l|l|}
\hline POSITION & Frequency & Percent & Valid \% & Cumulative \% \\
\hline Valid & Manager/Supervisor & 46 & 51.1 & 68.7 & 68.7 \\
\hline & Executive/Owner & 6 & 6.7 & 9.0 & 77.6 \\
\hline & HR Professional & 15 & 16.7 & 22.4 & 100.0 \\
\hline & Total & 67 & 74.4 & 100 & \\
\hline Missing & System & 23 & 25.6 & & \\
\hline Total & 90 & 100 & & \\
\hline
\end{tabular}

\begin{tabular}{|l|l|l|l|l|l|}
\hline YEARS OF SERVICE & Frequency & Percent & Valid \% & Cumulative \% \\
\hline Valid & Less than 1 year & 11 & 12.2 & 15.9 & 15.9 \\
\hline & $1-3$ years & 31 & 34.4 & 44.9 & 60.9 \\
\hline & 4-6 years & 22 & 24.4 & 31.9 & 92.8 \\
\hline & 7-10 years & 2 & 2.2 & 2.9 & 95.7 \\
\hline & More than 10 years & 3 & 3.3 & 4.3 & 100 \\
\hline & Total & 69 & 76.7 & 100 & \\
\hline Missing & System & 21 & 23.3 & & \\
\hline
\end{tabular}




\begin{tabular}{|l|l|l|l|l|l|}
\hline DEAF EMPLYMENT & Frequency & Percent & Valid \% & Cumulative \% \\
\hline Valid & No & 49 & 54.4 & 72.1 & 72.1 \\
\hline & Yes & 19 & 21.1 & 27.9 & 100 \\
\hline & Total & 68 & 75.6 & 100 & \\
\hline Missing & System & 22 & 24.4 & & \\
\hline Total & 90 & 100 & & \\
\hline
\end{tabular}

\begin{tabular}{|c|c|c|c|c|c|}
\hline \multicolumn{2}{|c|}{ INDUSTRY CLASSIFICATION } & NO. & $\%$ & V. $\%$ & C. $\%$ \\
\hline \multirow{22}{*}{ Valid } & Accommodation and Food Service Activities & 2 & 2.2 & 2.9 & 5.8 \\
\hline & Activities of Private Households & 0 & 0 & 0 & 0 \\
\hline & Activities of Extraterritorial organizations and bodies & 0 & 0 & 0 & 0 \\
\hline & Administrative and Support Service Activities & 7 & 7.8 & 10.1 & 29 \\
\hline & Agriculture, Forestry and Fishing & 0 & 0 & 0 & 0 \\
\hline & Arts, Entertainment and Recreation & 0 & 0 & 0 & 0 \\
\hline & Construction & 2 & 2.2 & 2.9 & 89.9 \\
\hline & Education & 1 & 1.1 & 1.4 & 95.7 \\
\hline & Electricity, Gas, Steam and Air Conditioning Supply & 1 & 1.1 & 1.4 & 95.7 \\
\hline & Financial and Insurance Activities & 15 & 16.7 & 21.7 & 50.7 \\
\hline & Human health and social work activities & 4 & 4.4 & 5.8 & 76.8 \\
\hline & Information and Communication & 8 & 8.9 & 11.6 & 18.8 \\
\hline & Manufacturing & 4 & 4.4 & 5.8 & 85.5 \\
\hline & Mining and Quarrying & 1 & 1.1 & 1.4 & 7.2 \\
\hline & Other Service Activities & 14 & 15.6 & 20.3 & 71 \\
\hline & Professional, Scientific and Technical Services & 2 & 2.2 & 2.9 & 92.8 \\
\hline & Public Administrative, Defense, Compulsory Social Sec & 1 & 1.1 & 1.4 & 100 \\
\hline & Real Estate Activities & 2 & 2.2 & 2.9 & 2.9 \\
\hline & Transportation and Storage & 2 & 2.2 & 2.9 & 98.6 \\
\hline & Water Supply, Sewerage, Waste Management & 1 & 1.1 & 1.4 & 87 \\
\hline & Wholesale and Retail Trade & 2 & 2.2 & 2.9 & 79.7 \\
\hline & Total & 69 & 76.7 & 100 & \\
\hline Missing & System & 21 & 23.3 & & \\
\hline \multicolumn{2}{|l|}{ Total } & 90 & 100 & & \\
\hline
\end{tabular}

DEMOGRAPHIC RESULTS: EMPLOYEES

\begin{tabular}{|c|c|c|c|c|c|c|c|}
\hline & Age & Sex & Education & Position & Experience & Job Status & Industry \\
\hline Valid & 21 & 21 & 21 & 21 & 21 & 21 & 21 \\
\hline Missing & 1 & 1 & 1 & 1 & 1 & 1 & 1 \\
\hline
\end{tabular}

FREQUENCY TABLES

\begin{tabular}{|l|l|l|l|l|l|}
\hline \multirow{2}{*}{ AGE } & Frequency & Percent & Valid \% & Cumulative \% \\
\hline \multirow{4}{*}{ Valid } & $18-29$ & 12 & 54.5 & 57.1 & 57.1 \\
\cline { 2 - 6 } & $30-41$ & 8 & 36.4 & 38.1 & 95.2 \\
\cline { 2 - 6 } & $42-53$ & 1 & 4.5 & 4.8 & 100 \\
\cline { 2 - 6 } & Total & 21 & 95.5 & 100 & \\
\hline Missing & System & 1 & 4.5 & & \\
\hline
\end{tabular}




\begin{tabular}{|c|c|c|c|c|c|}
\hline \multicolumn{2}{|l|}{ Total } & 22 & 100 & & \\
\hline \multicolumn{2}{|l|}{ SEX } & Frequency & Percent & Valid \% & Cumulative $\%$ \\
\hline \multirow{3}{*}{ Valid } & Female & 11 & 50.0 & 52.4 & 52.4 \\
\hline & Male & 10 & 45.5 & 47.6 & 100.0 \\
\hline & Total & 21 & 95.5 & 100.0 & \\
\hline Missing & System & 1 & 4.5 & & \\
\hline \multicolumn{2}{|l|}{ Total } & 22 & 100 & & \\
\hline
\end{tabular}

\begin{tabular}{|l|l|l|l|l|l|}
\hline EDUCATIONAL BACKGROUND & Frequency & Percent & Valid \% & Cumulative \% \\
\hline \multirow{4}{*}{ Valid } & bachelors & 15 & 68.2 & 71.4 & 71.4 \\
\cline { 2 - 6 } & masters & 0 & 0 & 0 & 0 \\
\cline { 2 - 6 } & high school or equivalent & 4 & 18.2 & 19.0 & 90.5 \\
\cline { 2 - 6 } & Training program & 2 & 9.1 & 9.5 & 100 \\
\cline { 2 - 6 } & Total & 21 & 95.5 & 100 & \\
\hline Missing & System & 1 & 4.5 & & \\
\hline Total & 22 & 100 & & \\
\hline
\end{tabular}

\begin{tabular}{|l|l|l|l|l|l|}
\hline POSITION & Frequency & Percent & Valid \% & Cumulative \% \\
\hline \multirow{4}{*}{ Valid } & Professional & 8 & 36.4 & 38.1 & 38.1 \\
\cline { 2 - 6 } & Production/Staff & 12 & 54.5 & 57.1 & 95.2 \\
\cline { 2 - 6 } & Manager/Supervisor & 1 & 4.5 & 4.8 & 100 \\
\cline { 2 - 6 } & Total & 21 & 95.5 & 100 & \\
\hline Missing & System & 1 & 4.5 & & \\
\hline Total & 22 & 100 & & \\
\hline
\end{tabular}

\begin{tabular}{|l|l|l|l|l|l|}
\hline YEARS OF SERVICE & Frequency & Percent & Valid \% & Cumulative \% \\
\hline \multirow{5}{*}{ Valid } & Less than 1 year & 5 & 22.7 & 23.8 & 23.8 \\
\cline { 2 - 6 } & $1-3$ years & 10 & 45.5 & 47.6 & 71.4 \\
\cline { 2 - 6 } & 4-6 years & 3 & 13.6 & 14.3 & 85.7 \\
\cline { 2 - 6 } & $7-10$ years & 2 & 9.1 & 9.5 & 95.2 \\
\cline { 2 - 6 } & More than 10 years & 1 & 4.5 & 4.8 & 100 \\
\cline { 2 - 6 } & Total & 21 & 95.5 & 100 & \\
\hline Missing & System & 1 & 4.5 & & \\
\hline Total & 22 & 100 & & \\
\hline
\end{tabular}

\begin{tabular}{|l|l|l|l|l|l|}
\hline \multirow{2}{*}{ JOB STA US } & Frequency & Percent & Valid \% & Cumulative \% \\
\hline \multirow{4}{*}{ Valid } & Full-time & 17 & 77.3 & 81 & 81 \\
\cline { 2 - 6 } & Part-time & 2 & 9.1 & 9.5 & 90.5 \\
\cline { 2 - 6 } & Project-based & 2 & 9.1 & 9.5 & 100 \\
\cline { 2 - 6 } & Total & 21 & 95.5 & 100 & \\
\hline Missing & System & 1 & 4.5 & & \\
\hline Total & 22 & 100 & & \\
\hline
\end{tabular}

\begin{tabular}{|c|c|c|c|c|c|}
\hline \multicolumn{2}{|c|}{ INDUSTRY CLASSIFICATION } & NO. & $\%$ & V. \% & C. $\%$ \\
\hline \multirow{4}{*}{ Valid } & Accommodation and Food Service Activities & 2 & 9.1 & 9.5 & 38.1 \\
\hline & Activities of Private Households & 0 & 0 & 0 & 0 \\
\hline & Activities of Extraterritorial organizations and bodies & 0 & 0 & 0 & 0 \\
\hline & Administrative and Support Service Activities & 3 & 13.6 & 14.3 & 14.3 \\
\hline
\end{tabular}




\begin{tabular}{|c|c|c|c|c|c|}
\hline & Agriculture, Forestry and Fishing & 0 & 0 & 0 & 0 \\
\hline & Arts, Entertainment and Recreation & 2 & 9.1 & 9.5 & 100 \\
\hline & Construction & 1 & 4.5 & 4.8 & 19 \\
\hline & Education & 1 & 4.5 & 4.8 & 23.8 \\
\hline & Electricity, Gas, Steam and Air Conditioning Supply & 0 & 0 & 0 & 0 \\
\hline & Financial and Insurance Activities & 0 & 0 & 0 & 0 \\
\hline & Human health and social work activities & 2 & 9.1 & 9.5 & 90.5 \\
\hline & Information and Communication & 2 & 9.1 & 9.5 & 76.2 \\
\hline & Manufacturing & 1 & 4.5 & 4.8 & 28.6 \\
\hline & Mining and Quarrying & 0 & 0 & 0 & 0 \\
\hline & Other Service Activities & 6 & 27.3 & 28.6 & 66.7 \\
\hline & Professional, Scientific and Technical Services & 1 & 4.5 & 4.8 & 81 \\
\hline & Public Administrative, Defense, Compulsory Social Sec & 0 & 0 & 0 & 0 \\
\hline & Real Estate Activities & 0 & 0 & 0 & 0 \\
\hline & Transportation and Storage & 0 & 0 & 0 & 0 \\
\hline & Water Supply, Sewerage, Waste Management & 0 & 0 & 0 & 0 \\
\hline & Wholesale and Retail Trade & 0 & 0 & 0 & 0 \\
\hline & Total & 21 & 95.5 & 100 & \\
\hline Missing & System & 1 & 4.5 & & \\
\hline Total & & 22 & 100 & & \\
\hline & & Per & C.\%: & mulati & Percent \\
\hline
\end{tabular}




\begin{tabular}{|c|c|c|c|c|c|c|c|c|c|c|c|c|c|}
\hline \multicolumn{14}{|c|}{ ATDS - STATISTICS } \\
\hline & & & Q1 & Q2 & Q3 & Q4 & Q5 & Q6 & Q7 & Q8 & Q9 & Q10 & Q11 \\
\hline \multirow{2}{*}{$\mathrm{N}$} & \multicolumn{2}{|c|}{ Valid } & 69 & 69 & 68 & 69 & 69 & 69 & 69 & 69 & 69 & 69 & 67 \\
\hline & \multicolumn{2}{|c|}{ Missing } & 21 & 21 & 22 & 21 & 21 & 21 & 21 & 21 & 21 & 21 & 23 \\
\hline \multicolumn{3}{|c|}{ Mean } & 4.0435 & 3.8261 & 4.9412 & 2.5217 & 2.5072 & 2.7971 & 5.2174 & 4.7826 & 2.8551 & 3.1304 & 4.7313 \\
\hline \multicolumn{3}{|c|}{ Std. Deviation } & 1.67538 & 1.82270 & 1.02042 & 1.64145 & 1.42068 & 1.57722 & 1.39188 & 1.24699 & 1.62042 & 1.23566 & 1.06717 \\
\hline & & & Q12 & Q13 & Q14 & Q15 & Q16 & Q17 & Q18 & Q19 & Q20 & Q21 & Q22 \\
\hline \multirow[b]{2}{*}{$\mathrm{N}$} & \multicolumn{2}{|c|}{ Valid } & 69 & 68 & 69 & 69 & 69 & 68 & 69 & 69 & 69 & 69 & 69 \\
\hline & \multicolumn{2}{|c|}{ Missing } & 21 & 22 & 21 & 21 & 21 & 22 & 21 & 21 & 21 & 21 & 21 \\
\hline \multicolumn{3}{|c|}{ Mean } & 4.4203 & 4.2059 & 4.5797 & 4.4348 & 1.5942 & 1.7941 & 2.6087 & 4.5507 & 5.1159 & 2.3333 & 3.6087 \\
\hline \multicolumn{3}{|c|}{ Std. Deviation } & 1.47933 & 1.59812 & 1.34389 & 1.36638 & 1.21654 & 1.04466 & 1.45741 & 1.37772 & .93205 & 1.29099 & 1.56447 \\
\hline \multirow{2}{*}{\multicolumn{14}{|c|}{ ATTITUDE TO DEAFNESS SCALE (ATDS) }} \\
\hline \multirow{2}{*}{\multicolumn{5}{|c|}{ S1: Deaf couples should receive genetic }} & & & & & & & & & \\
\hline & & & & & \multicolumn{3}{|c|}{ Frequency } & \multicolumn{2}{|c|}{ Percent } & \multicolumn{2}{|c|}{ Valid \% } & \multicolumn{2}{|c|}{ Cumulative $\%$} \\
\hline & & & ongly Dis & agree & & 8 & & 8.9 & & 11.6 & & 11 & \\
\hline & & & sagree & & & 7 & & 7.8 & & 10.1 & & 21 & \\
\hline & & & ghtly Disa & gree & & 8 & & 8.9 & & 11.6 & & 33 & \\
\hline & & & ghtly Agr & & & 14 & & 15.6 & & 20.3 & & 53 & \\
\hline & & & ree & & & 15 & & 16.7 & & 21.7 & & 75 & \\
\hline & & & ongly Ag1 & & & 17 & & 18.9 & & 24.6 & & 10 & \\
\hline & & To & & & & 69 & & 76.7 & & 100 & & & \\
\hline & & & & & & 21 & & 23.3 & & & & & \\
\hline & & & & & & 90 & & 100 & & & & & \\
\hline & $a f c$ & & should le & n to sp & to con & lunicate $\mathrm{w}$ & th heal & arents. & & & & & \\
\hline & & & & & & requency & & Percent & & Valid & & Cumuli & tive $\%$ \\
\hline & & & ongly Dis & agree & & 8 & & 8.9 & & 11.6 & & 11 & \\
\hline & & & sagree & & & 13 & & 14.4 & & 18.8 & & 30 & \\
\hline & & & ghtly Disa & gree & & 11 & & 12.2 & & 15.9 & & 46 & \\
\hline & & & ghtly Agr & & & 10 & & 11.1 & & 14.5 & & 60 & \\
\hline & & & ree & & & 5 & & 5.6 & & 7.2 & & 68 & \\
\hline & & & ongly Ag1 & & & 22 & & 24.4 & & 31.9 & & 10 & \\
\hline & & To & & & & 69 & & 76.7 & & 100 & & & \\
\hline & & & & & & 21 & & 23.3 & & & & & \\
\hline & & & & & & 90 & & 100 & & & & & \\
\hline & $3:$ I v & & ke to have & more de & friends. & & & & & & & & \\
\hline & & & & & & requency & & Percent & & Valid & & Cumula & tive $\%$ \\
\hline & & & ongly Dis & agree & & 0 & & 0 & & 0 & & ( & \\
\hline & & & sagree & & & 1 & & 1.1 & & 1.5 & & 1. & \\
\hline & & & ghtly Disa & gree & & 5 & & 5.6 & & 7.4 & & 8. & \\
\hline & & & ghtly Agr & & & 16 & & 17.8 & & 23.5 & & 32 & \\
\hline & & & ree & & & 21 & & 23.3 & & 30.9 & & 63 & \\
\hline & & & ongly Agr & & & 25 & & 27.8 & & 36.8 & & 10 & \\
\hline & & To & & & & 68 & & 75.6 & & 100 & & & \\
\hline & & & & & & 22 & & 24 & & & & & \\
\hline & & & & & & 90 & & 100 & & & & & \\
\hline & eàl s & 100 & and deaf $\mathrm{c}$ & lubs crea & deaf 'ghe & 'ttos'. & & & & & & & \\
\hline & & & & & & requency & & Percent & & Valid & & Cumula & tive $\%$ \\
\hline & & & ongly Dis & agree & & 24 & & 26.7 & & 34.8 & & 34 & \\
\hline & & & sagree & & & 20 & & 22.2 & & 29 & & 63 & \\
\hline & & & ghtly Disa & gree & & 7 & & 7.8 & & 10.1 & & 73 & \\
\hline
\end{tabular}




\begin{tabular}{|c|c|c|c|c|c|}
\hline & 4 Slightly Agree & 8 & 8.9 & 11.6 & 85.5 \\
\hline & 5 Agree & 3 & 3.3 & 4.3 & 89.9 \\
\hline & 6 Strongly Agree & 7 & 7.8 & 10.1 & 100 \\
\hline & Total & 69 & 76.7 & 100 & \\
\hline Missing & System & 21 & 23.3 & & \\
\hline \multicolumn{2}{|l|}{ Total } & 90 & 100 & & \\
\hline \multicolumn{6}{|c|}{ S5: Deaf people should learn speech rather than sign language. } \\
\hline & & Frequency & Percent & Valid \% & Cumulative $\%$ \\
\hline \multirow{7}{*}{ Valid } & 1 Strongly Disagree & 22 & 24.4 & 31.9 & 31.9 \\
\hline & 2 Disagree & 15 & 16.7 & 21.7 & 53.6 \\
\hline & 3 Slightly Disagree & 16 & 17.8 & 23.2 & 76.8 \\
\hline & 4 Slightly Agree & 11 & 12.2 & 15.9 & 92.8 \\
\hline & 5 Agree & 1 & 1.1 & 1.4 & 94.2 \\
\hline & 6 Strongly Agree & 4 & 4.4 & 5.8 & 100 \\
\hline & Total & 69 & 76.7 & 100 & \\
\hline Missing & System & 21 & 23.3 & & \\
\hline \multicolumn{2}{|l|}{ Total } & 90 & 100 & & \\
\hline \multicolumn{6}{|c|}{ S6: Deaf people are handicapped. } \\
\hline & & Frequency & Percent & Valid \% & Cumulative $\%$ \\
\hline \multirow{7}{*}{ Valid } & 1 Strongly Disagree & 23 & 25.6 & 33.3 & 33.3 \\
\hline & 2 Disagree & 7 & 7.8 & 10.1 & 43.5 \\
\hline & 3 Slightly Disagree & 13 & 14.4 & 18.8 & 62.3 \\
\hline & 4 Slightly Agree & 17 & 18.9 & 24.6 & 87 \\
\hline & 5 Agree & 5 & 5.6 & 7.2 & 94.2 \\
\hline & 6 Strongly Agree & 4 & 4.4 & 5.8 & 100 \\
\hline & Total & 69 & 76.7 & 100 & \\
\hline Missing & System & 21 & 23.3 & & \\
\hline \multicolumn{2}{|l|}{ Total } & 90 & 100 & & \\
\hline \multicolumn{6}{|c|}{ S7: More research should be done to find cures for deafness. } \\
\hline & & Frequency & Percent & Valid \% & Cumulative $\%$ \\
\hline \multirow{7}{*}{ Valid } & 1 Strongly Disagree & 4 & 4.4 & 5.8 & 5.8 \\
\hline & 2 Disagree & 2 & 2.2 & 2.9 & 8.7 \\
\hline & 3 Slightly Disagree & 1 & 1.1 & 1.4 & 10.1 \\
\hline & 4 Slightly Agree & 5 & 5.6 & 7.2 & 17.4 \\
\hline & 5 Agree & 13 & 14.4 & 18.8 & 36.2 \\
\hline & 6 Strongly Agree & 44 & 48.9 & 63.8 & 100 \\
\hline & Total & 69 & 76.7 & 100 & \\
\hline Missing & System & 21 & 23.3 & & \\
\hline \multicolumn{2}{|l|}{ Total } & 90 & 100 & & \\
\hline \multicolumn{6}{|c|}{ ***S8: Deaf children should be taught in sign language. } \\
\hline \multirow{7}{*}{ Valid } & 1 Strongly Disagree & 2 & 2.2 & 2.9 & 2.9 \\
\hline & 2 Disagree & 2 & 2.2 & 2.9 & 5.8 \\
\hline & 3 Slightly Disagree & 6 & 6.7 & 8.7 & 14.5 \\
\hline & 4 Slightly Agree & 12 & 13.3 & 17.4 & 31.9 \\
\hline & 5 Agree & 24 & 26.7 & 34.8 & 66.7 \\
\hline & 6 Strongly Agree & 23 & 25.6 & 33.3 & 100 \\
\hline & Total & 69 & 76.7 & 100 & \\
\hline Missing & System & 21 & 23.3 & & \\
\hline \multicolumn{2}{|c|}{ Total } & 90 & 100 & & \\
\hline \multicolumn{6}{|c|}{ S9: Hearing children of deaf parents are at risk of emotional deprivation. } \\
\hline \multirow{3}{*}{ Valid } & 1 Strongly Disagree & 18 & 20 & 26.1 & 26.1 \\
\hline & 2 Disagree & 15 & 16.7 & 21.7 & 47.8 \\
\hline & 3 Slightly Disagree & 15 & 16.7 & 21.7 & 69.6 \\
\hline
\end{tabular}




\begin{tabular}{|c|c|c|c|c|c|}
\hline & 4 Slightly Agree & 7 & 7.8 & 10.1 & 79.7 \\
\hline & 5 Agree & 8 & 8.9 & 11.6 & 91.3 \\
\hline & 6 Strongly Agree & 6 & 6.7 & 8.7 & 100 \\
\hline & Total & 69 & 76.7 & 100 & \\
\hline Missing & System & 21 & 23.3 & & \\
\hline \multicolumn{2}{|l|}{ Total } & 90 & 100 & & \\
\hline \multirow{8}{*}{ Valid } & at people are sate driv & Frequency & Percent & Valid \% & Cumulative $\%$ \\
\hline & 1 Strongly Disagree & 6 & 6.7 & 8.7 & 8.7 \\
\hline & 2 Disagree & 14 & 15.6 & 20.3 & 29 \\
\hline & 3 Slightly Disagree & 27 & 30 & 39.1 & 68.1 \\
\hline & 4 Slightly Agree & 12 & 13.3 & 17.4 & 85.5 \\
\hline & 5 Agree & 7 & 7.8 & 10.1 & 95.7 \\
\hline & 6 Strongly Agree & 3 & 3.3 & 4.3 & 100 \\
\hline & Total & 69 & 76.7 & 100 & \\
\hline Missing & System & 21 & 23.3 & & \\
\hline \multicolumn{2}{|c|}{ Total } & 90 & 100 & & \\
\hline \multicolumn{6}{|c|}{ ***S11: I would like to have more deaf colleagues. } \\
\hline & & Frequency & Percent & Valid \% & Cumulative \% \\
\hline \multirow{7}{*}{ Valid } & 1 Strongly Disagree & 0 & 0 & 0 & 0 \\
\hline & 2 Disagree & 1 & 1.1 & 1.5 & 1.5 \\
\hline & 3 Slightly Disagree & 7 & 7.8 & 10.4 & 11.9 \\
\hline & 4 Slightly Agree & 22 & 24.4 & 32.8 & 44.8 \\
\hline & 5 Agree & 16 & 17.8 & 23.9 & 68.7 \\
\hline & 6 Strongly Agree & 21 & 23.3 & 31.3 & 100 \\
\hline & Total & 67 & 74.4 & 100 & \\
\hline Missing & System & 23 & 25.6 & & \\
\hline \multicolumn{2}{|c|}{ Total } & 90 & 100 & & \\
\hline \multicolumn{6}{|c|}{ S12: Deaf people should learn to lip read. } \\
\hline & & Frequency & Percent & Valid \% & Cumulative $\%$ \\
\hline \multirow{7}{*}{ Valid } & 1 Strongly Disagree & 3 & 3.3 & 4.3 & 4.3 \\
\hline & 2 Disagree & 5 & 5.6 & 7.2 & 11.6 \\
\hline & 3 Slightly Disagree & 11 & 12.2 & 15.9 & 27.5 \\
\hline & 4 Slightly Agree & 13 & 14.4 & 18.8 & 46.4 \\
\hline & 5 Agree & 15 & 16.7 & 21.7 & 68.1 \\
\hline & 6 Strongly Agree & 22 & 24.4 & 31.9 & 100 \\
\hline & Total & 69 & 76.7 & 100 & \\
\hline Missing & System & 21 & 23.3 & & \\
\hline \multicolumn{2}{|c|}{ Total } & 90 & 100 & & \\
\hline \multicolumn{6}{|c|}{ ***S13: Interpreters should be available for deaf people at work. } \\
\hline \multirow{7}{*}{ Valid } & 1 Strongly Disagree & 6 & 6.7 & 8.8 & 8.8 \\
\hline & 2 Disagree & 6 & 6.7 & 8.8 & 17.6 \\
\hline & 3 Slightly Disagree & 7 & 7.8 & 10.3 & 27.9 \\
\hline & 4 Slightly Agree & 17 & 18.9 & 25 & 52.9 \\
\hline & 5 Agree & 13 & 14.4 & 19.1 & 72.1 \\
\hline & 6 Strongly Agree & 19 & 21.1 & 27.9 & 100 \\
\hline & Total & 68 & 75.6 & 100 & \\
\hline Missing & System & 22 & 24.4 & & \\
\hline \multicolumn{2}{|l|}{ Total } & 90 & 100 & & \\
\hline \multicolumn{6}{|l|}{ S14: Dec } \\
\hline \multirow{3}{*}{ Valid } & 1 Strongly Disagree & 2 & 2.2 & 2.9 & 2.9 \\
\hline & 2 Disagree & 3 & 3.3 & 4.3 & 7.2 \\
\hline & 3 Slightly Disagree & 8 & 8.9 & 11.6 & 18.8 \\
\hline
\end{tabular}




\begin{tabular}{|c|c|c|c|c|c|}
\hline & 4 Slightly Agree & 20 & 22.2 & 29 & 47.8 \\
\hline & 5 Agree & 12 & 13.3 & 17.4 & 65.2 \\
\hline & 6 Strongly Agree & 24 & 26.7 & 34.8 & 100 \\
\hline & Total & 69 & 76.7 & 100 & \\
\hline Missing & System & 21 & 23.3 & & \\
\hline \multicolumn{2}{|l|}{ Total } & 90 & 100 & & \\
\hline \multicolumn{6}{|c|}{ S15: All deaf people should be offered corrective surgery. } \\
\hline & & Frequency & Percent & Valid \% & Cumulative $\%$ \\
\hline \multirow{7}{*}{ Valid } & 1 Strongly Disagree & 3 & 3.3 & 4.3 & 4.3 \\
\hline & 2 Disagree & 2 & 2.2 & 2.9 & 7.2 \\
\hline & 3 Slightly Disagree & 11 & 12.2 & 15.9 & 23.2 \\
\hline & 4 Slightly Agree & 19 & 21.1 & 27.5 & 50.7 \\
\hline & 5 Agree & 14 & 15.6 & 20.3 & 71 \\
\hline & 6 Strongly Agree & 20 & 22.2 & 29 & 100 \\
\hline & Total & 69 & 76.7 & 100 & \\
\hline Missing & System & 21 & 23.3 & & \\
\hline \multicolumn{2}{|c|}{ Total } & 90 & 100 & & \\
\hline \multicolumn{6}{|c|}{ S16: Training more mental health professionals to work with deaf clients would be a waste of time. } \\
\hline & & Frequency & Percent & Valid \% & Cumulative $\%$ \\
\hline \multirow{7}{*}{ Valid } & 1 Strongly Disagree & 48 & 53.3 & 69.6 & 69.6 \\
\hline & 2 Disagree & 13 & 14.4 & 18.8 & 88.4 \\
\hline & 3 Slightly Disagree & 3 & 3.3 & 4.3 & 92.8 \\
\hline & 4 Slightly Agree & 1 & 1.1 & 1.4 & 94.2 \\
\hline & 5 Agree & 1 & 1.1 & 1.4 & 95.7 \\
\hline & 6 Strongly Agree & 3 & 3.3 & 4.3 & 100 \\
\hline & Total & 69 & 76.7 & 100 & \\
\hline Missing & System & 21 & 23.3 & & \\
\hline \multicolumn{2}{|c|}{ Total } & 90 & 100 & & \\
\hline \multicolumn{6}{|c|}{ S17: Having a deaf colleague would cause problems in the workplace. } \\
\hline & & Frequency & Percent & Valid \% & Cumulative $\%$ \\
\hline \multirow{7}{*}{ Valid } & 1 Strongly Disagree & 34 & 37.8 & 50 & 50 \\
\hline & 2 Disagree & 21 & 23.3 & 30.9 & 80.9 \\
\hline & 3 Slightly Disagree & 9 & 10 & 13.2 & 94.1 \\
\hline & 4 Slightly Agree & 2 & 2.2 & 2.9 & 97.1 \\
\hline & 5 Agree & 1 & 1.1 & 1.5 & 98.5 \\
\hline & 6 Strongly Agree & 1 & 1.1 & 1.5 & 100 \\
\hline & Total & 68 & 75.6 & 100 & \\
\hline Missing & System & 22 & 24.4 & & \\
\hline \multicolumn{2}{|c|}{ Total } & 90 & 100 & & \\
\hline \multicolumn{6}{|c|}{ S18: Deaf people are physiologically impaired. } \\
\hline & & Frequency & Percent & Valid \% & Cumulative $\%$ \\
\hline \multirow{7}{*}{ Valid } & 1 Strongly Disagree & 21 & 23.3 & 30.4 & 30.4 \\
\hline & 2 Disagree & 16 & 17.8 & 23.2 & 53.6 \\
\hline & 3 Slightly Disagree & 10 & 11.1 & 14.5 & 68.1 \\
\hline & 4 Slightly Agree & 16 & 17.8 & 23.2 & 91.3 \\
\hline & 5 Agree & 3 & 3.3 & 4.3 & 95.7 \\
\hline & 6 Strongly Agree & 3 & 3.3 & 4.3 & 100 \\
\hline & Total & 69 & 76.7 & 100 & \\
\hline Missing & System & 21 & 23.3 & & \\
\hline \multicolumn{2}{|c|}{ Total } & 90 & 100 & & \\
\hline & & Frequency & Percent & Valid \% & Cumulative $\%$ \\
\hline \multirow{3}{*}{ Valid } & 1 Strongly Disagree & 2 & 2.2 & 2.9 & 2.9 \\
\hline & 2 Disagree & 4 & 4.4 & 5.8 & 8.7 \\
\hline & 3 Slightly Disagree & 11 & 12.2 & 15.9 & 24.6 \\
\hline
\end{tabular}




\begin{tabular}{|c|c|c|c|c|c|}
\hline & 4 Slightly Agree & 10 & 11.1 & 14.5 & 39.1 \\
\hline & 5 Agree & 21 & 23.3 & 30.4 & 69.6 \\
\hline & 6 Strongly Agree & 21 & 23.3 & 30.4 & 100 \\
\hline & Total & 69 & 76.7 & 100 & \\
\hline Missing & System & 21 & 23.3 & & \\
\hline \multicolumn{2}{|l|}{ Total } & 90 & 100 & & \\
\hline \multicolumn{6}{|c|}{ ***S20: I would like to see more deaf pe } \\
\hline \multirow{7}{*}{ Valid } & 1 Strongly Disagree & 0 & 0 & 0 & 0 \\
\hline & 2 Disagree & 1 & 1.1 & 1.4 & 1.4 \\
\hline & 3 Slightly Disagree & 3 & 3.3 & 4.3 & 5.8 \\
\hline & 4 Slightly Agree & 11 & 12.2 & 15.9 & 21.7 \\
\hline & 5 Agree & 26 & 28.9 & 37.7 & 59.4 \\
\hline & 6 Strongly Agree & 28 & 31.1 & 40.6 & 100 \\
\hline & Total & 69 & 76.7 & 100 & \\
\hline Missing & System & 21 & 23.3 & & \\
\hline \multicolumn{2}{|l|}{ Total } & 90 & 100 & & \\
\hline \multicolumn{6}{|c|}{ S21: Having a deaf friend would be difficult. } \\
\hline & & Frequency & Percent & Valid \% & Cumulative $\%$ \\
\hline \multirow{7}{*}{ Valid } & 1 Strongly Disagree & 23 & 25.6 & 33.3 & 33.3 \\
\hline & 2 Disagree & 19 & 21.1 & 27.5 & 60.9 \\
\hline & 3 Slightly Disagree & 14 & 15.6 & 20.3 & 81.2 \\
\hline & 4 Slightly Agree & 8 & 8.9 & 11.6 & 92.8 \\
\hline & 5 Agree & 4 & 4.4 & 5.8 & 98.6 \\
\hline & 6 Strongly Agree & 1 & 1.1 & 1.4 & 100 \\
\hline & Total & 69 & 76.7 & 100 & \\
\hline Missing & System & 21 & 23.3 & & \\
\hline \multicolumn{2}{|c|}{ Total } & 90 & 100 & & \\
\hline \multicolumn{6}{|c|}{ ***S22: Deaf people have their own culture. } \\
\hline \multirow{7}{*}{ Valid } & 1 Strongly Disagree & 6 & 6.7 & 8.7 & 8.7 \\
\hline & 2 Disagree & 15 & 16.7 & 21.7 & 30.4 \\
\hline & 3 Slightly Disagree & 10 & 11.1 & 14.5 & 44.9 \\
\hline & 4 Slightly Agree & 18 & 20.0 & 26.1 & 71 \\
\hline & 5 Agree & 9 & 10.0 & 13 & 84.1 \\
\hline & 6 Strongly Agree & 11 & 12.2 & 15.9 & 100 \\
\hline & Total & 69 & 76.7 & 100 & \\
\hline Missing & System & 21 & 23.3 & & \\
\hline \multicolumn{2}{|l|}{ Total } & 90 & 100 & & \\
\hline
\end{tabular}




\begin{tabular}{|l|l|l|l|l|l|l|l|l|l|l|l|}
\hline \multicolumn{2}{|c|}{} & Q1 & Q2 & Q3 & Q4 & Q5 & Q6 & Q7 & Q8 & Q9 & Q10 \\
\hline \multirow{2}{*}{$\mathrm{N}$} & Valid & 69 & 69 & 69 & 69 & 69 & 69 & 69 & 68 & 69 & 69 \\
\cline { 2 - 12 } & Missing & 21 & 21 & 21 & 21 & 21 & 21 & 21 & 22 & 21 & 21 \\
\hline \multirow{2}{*}{ Mean } & 3.3188 & 2.2609 & 3.3768 & 3.3333 & 1.8841 & 2.1304 & 3.3478 & 2.3824 & 1.6087 & 3.5652 \\
\hline \multicolumn{2}{|l|}{ Std. Deviation } & .67503 & .79802 & .66645 & .70014 & .86664 & .92216 & .70348 & .97780 & .84396 & .71698 \\
\hline
\end{tabular}

\section{S1: On the whole, I am satisfied with myself.}

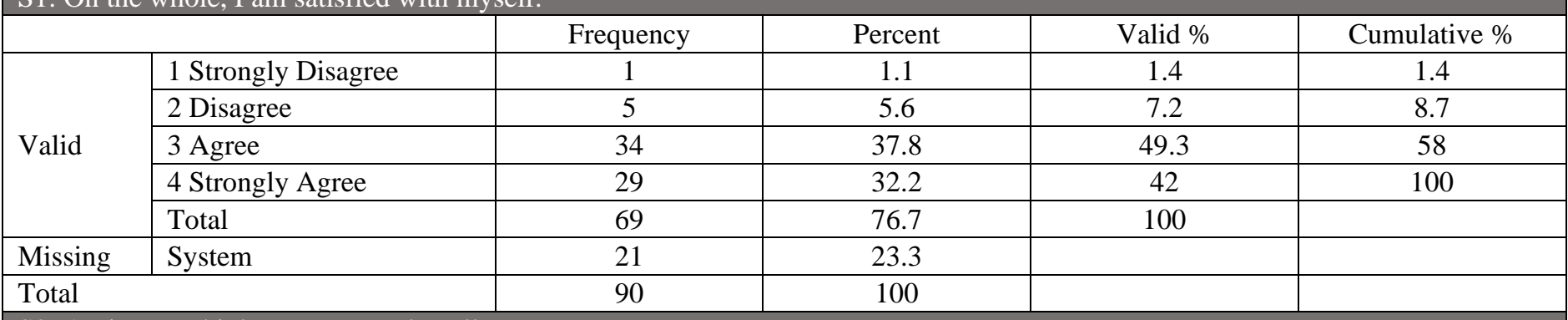

\section{S2: At times, I think I am no good at all.}

\begin{tabular}{|l|l|c|c|c|c|}
\hline \multicolumn{2}{|c|}{} & Frequency & Percent & Valid \% & Cumulative \% \\
\hline \multirow{4}{*}{ Valid } & 1 Strongly Disagree & 12 & 13.3 & 17.4 & 17.4 \\
\cline { 2 - 6 } & 2 Disagree & 30 & 33.3 & 43.5 & 60.9 \\
\cline { 2 - 6 } & 3 Agree & 24 & 26.7 & 34.8 & 95.7 \\
\cline { 2 - 6 } & 4 Strongly Agree & 3 & 3.3 & 4.3 & 100 \\
\cline { 2 - 6 } & Total & 69 & 76.7 & 100 & \\
\hline Missing & System & 21 & 23.3 & & \\
\hline \multicolumn{2}{|l|}{ Total } & 90 & 100 & & \\
\hline
\end{tabular}

S3: I feel that I have a number of good qualities.

\begin{tabular}{|l|l|c|c|c|c|}
\hline \multicolumn{2}{|c|}{} & Frequency & Percent & Valid \% & Cumulative \% \\
\hline \multirow{4}{*}{ Valid } & 1 Strongly Disagree & 1 & 1.1 & 1.4 & 1.4 \\
\cline { 2 - 6 } & 2 Disagree & 4 & 4.4 & 5.8 & 7.2 \\
\cline { 2 - 6 } & 3 Agree & 32 & 35.6 & 46.4 & 53.6 \\
\cline { 2 - 6 } & 4 Strongly Agree & 32 & 35.6 & 46.4 & 100 \\
\cline { 2 - 6 } & Total & 69 & 76.7 & 100 & \\
\hline Missing & System & 21 & 23.3 & & \\
\hline \multicolumn{2}{|l|}{ Total } & 90 & 100 & & \\
\hline
\end{tabular}

\begin{tabular}{|c|c|c|c|c|c|}
\hline & & Frequency & Percent & Valid \% & Cumulative $\%$ \\
\hline \multirow{5}{*}{ Valid } & 1 Strongly Disagree & 1 & 1.1 & 1.4 & 1.4 \\
\hline & 2 Disagree & 6 & 6.7 & 8.7 & 10.1 \\
\hline & 3 Agree & 31 & 34.4 & 44.9 & 55.1 \\
\hline & 4 Strongly Agree & 31 & 34.4 & 44.9 & 100 \\
\hline & Total & 69 & 76.7 & 100 & \\
\hline Missing & System & 21 & 23.3 & & \\
\hline \multicolumn{2}{|c|}{ Total } & 90 & 100 & & \\
\hline \multicolumn{6}{|c|}{ S5: I feel I do not have much to be proud of. } \\
\hline & & Frequency & Percent & Valid \% & Cumulative $\%$ \\
\hline \multirow{5}{*}{ Valid } & 1 Strongly Disagree & 26 & 28.9 & 37.7 & 37.7 \\
\hline & 2 Disagree & 29 & 32.2 & 42.0 & 79.7 \\
\hline & 3 Agree & 10 & 11.1 & 14.5 & 94.2 \\
\hline & 4 Strongly Agree & 4 & 4.4 & 5.8 & 100 \\
\hline & Total & 69 & 76.7 & 100 & \\
\hline
\end{tabular}




\begin{tabular}{|c|c|c|c|c|c|}
\hline Missing & System & 21 & 23.3 & & \\
\hline \multicolumn{2}{|c|}{ Total } & 90 & 100 & & \\
\hline \multicolumn{6}{|c|}{ S6: I certainly feel useless at times. } \\
\hline & & Frequency & Percent & Valid \% & Cumulative $\%$ \\
\hline \multirow{5}{*}{ Valid } & 1 Strongly Disagree & 19 & 21.1 & 27.5 & 27.5 \\
\hline & 2 Disagree & 28 & 31.1 & 40.6 & 68.1 \\
\hline & 3 Agree & 16 & 17.8 & 23.2 & 91.3 \\
\hline & 4 Strongly Agree & 6 & 6.7 & 8.7 & 100 \\
\hline & Total & 69 & 76.7 & 100 & \\
\hline Missing & System & 21 & 23.3 & & \\
\hline \multicolumn{2}{|l|}{ Total } & 90 & 100 & & \\
\hline \multicolumn{6}{|c|}{ S7: I feel that I'm a person of worth, at least on an equal plane with others. } \\
\hline & & Frequency & Percent & Valid \% & Cumulative \% \\
\hline \multirow{5}{*}{ Valid } & 1 Strongly Disagree & 2 & 2.2 & 2.9 & 2.9 \\
\hline & 2 Disagree & 3 & 3.3 & 4.3 & 7.2 \\
\hline & 3 Agree & 33 & 36.7 & 47.8 & 55.1 \\
\hline & 4 Strongly Agree & 31 & 34.4 & 44.9 & 100 \\
\hline & Total & 69 & 76.7 & 100 & \\
\hline Missing & System & 21 & 23.3 & & \\
\hline \multicolumn{2}{|c|}{ Total } & 90 & 100 & & \\
\hline \multicolumn{6}{|c|}{ S8: I wish I could have more respect for myself. } \\
\hline & & Frequency & Percent & Valid \% & Cumulative $\%$ \\
\hline \multirow{5}{*}{ Valid } & 1 Strongly Disagree & 13 & 14.4 & 19.1 & 19.1 \\
\hline & 2 Disagree & 27 & 30 & 39.7 & 58.8 \\
\hline & 3 Agree & 17 & 18.9 & 25 & 83.8 \\
\hline & 4 Strongly Agree & 11 & 12.2 & 16.2 & 100 \\
\hline & Total & 68 & 75.6 & 100 & \\
\hline Missing & System & 22 & 24.4 & & \\
\hline \multicolumn{2}{|c|}{ Total } & 90 & 100 & & \\
\hline \multicolumn{6}{|c|}{ S9: All in all, I am inclined to feel that I am a failure. } \\
\hline & & Frequency & Percent & Valid \% & Cumulative $\%$ \\
\hline \multirow{5}{*}{ Valid } & 1 Strongly Disagree & 40 & 44.4 & 58 & 58 \\
\hline & 2 Disagree & 19 & 21.1 & 27.5 & 85.5 \\
\hline & 3 Agree & 7 & 7.8 & 10.1 & 95.7 \\
\hline & 4 Strongly Agree & 3 & 3.3 & 4.3 & 100 \\
\hline & Total & 69 & 76.7 & 100 & \\
\hline Missing & System & 21 & 23.3 & & \\
\hline \multicolumn{2}{|l|}{ Total } & 90 & 100 & & \\
\hline \multicolumn{6}{|c|}{ S10: I take a positive attitude toward myself. } \\
\hline & & Frequency & Percent & Valid \% & Cumulative $\%$ \\
\hline \multirow{5}{*}{ Valid } & 1 Strongly Disagree & 2 & 2.2 & 2.9 & 2.9 \\
\hline & 2 Disagree & 3 & 3.3 & 4.3 & 7.2 \\
\hline & 3 Agree & 18 & 20.0 & 26.1 & 33.3 \\
\hline & 4 Strongly Agree & 46 & 51.1 & 66.7 & 100 \\
\hline & Total & 69 & 76.7 & 100 & \\
\hline Missing & System & 21 & 23.3 & & \\
\hline \multicolumn{2}{|l|}{ Total } & 90 & 100 & & \\
\hline
\end{tabular}




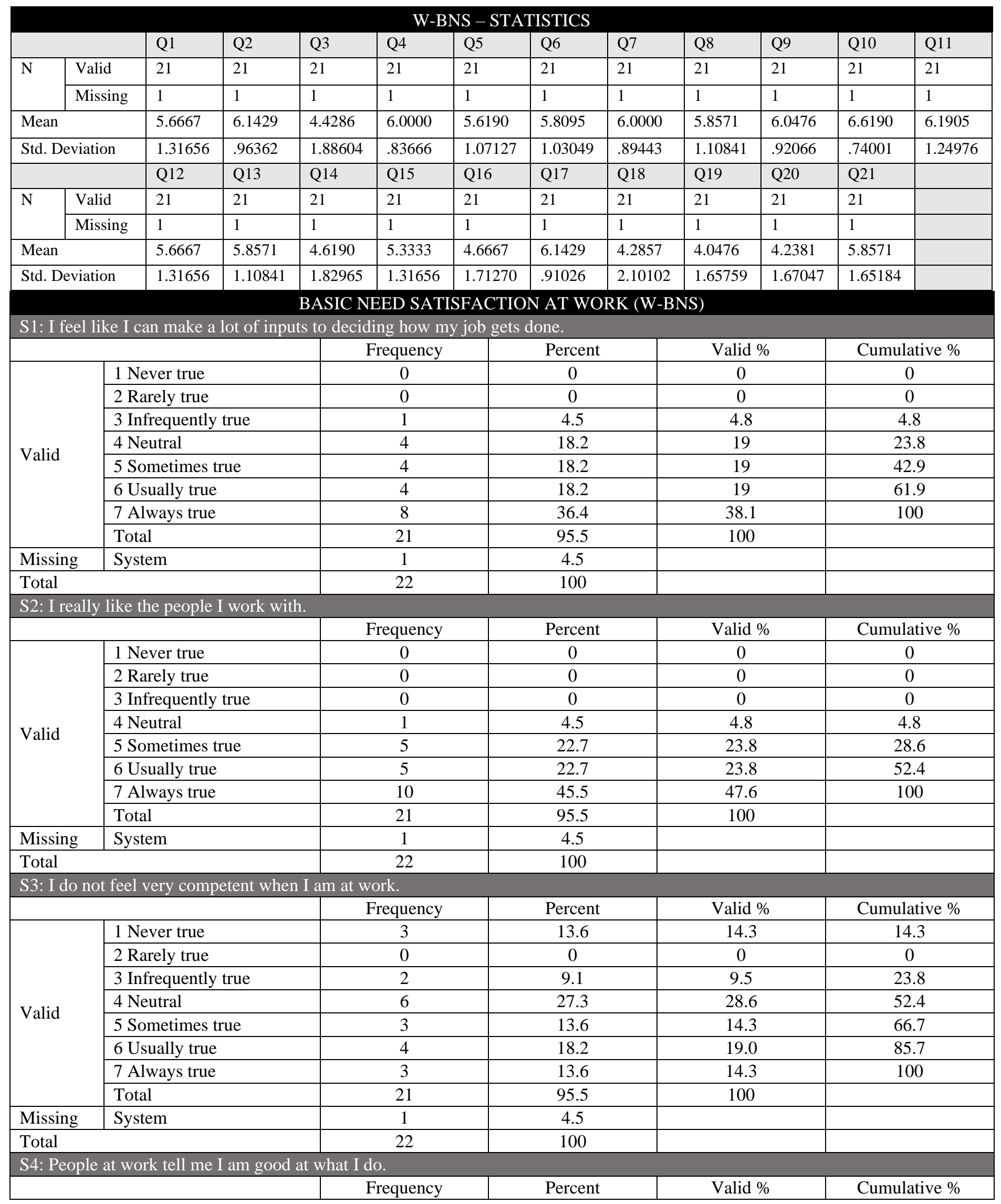




\begin{tabular}{|c|c|c|c|c|c|}
\hline \multirow{8}{*}{ Valid } & 1 Never true & 0 & 0 & 0 & 0 \\
\hline & 2 Rarely true & 0 & 0 & 0 & 0 \\
\hline & 3 Infrequently true & 0 & 0 & 0 & 0 \\
\hline & 4 Neutral & 0 & 0 & 0 & 0 \\
\hline & 5 Sometimes true & 7 & 31.8 & 33.3 & 33.3 \\
\hline & 6 Usually true & 7 & 31.8 & 33.3 & 66.7 \\
\hline & 7 Always true & 7 & 31.8 & 33.3 & 100 \\
\hline & Total & 21 & 95.5 & 100 & \\
\hline Missing & System & 1 & 4.5 & & \\
\hline \multicolumn{2}{|c|}{ Total } & 22 & 100 & & \\
\hline \multicolumn{6}{|c|}{ S5: I feel pressured at work. } \\
\hline & & Frequency & Percent & Valid \% & Cumulative $\%$ \\
\hline \multirow{8}{*}{ Valid } & 1 Never true & 0 & 0 & 0 & 0 \\
\hline & 2 Rarely true & 0 & 0 & 0 & 0 \\
\hline & 3 Infrequently true & 0 & 0 & 0 & 0 \\
\hline & 4 Neutral & 4 & 18.2 & 19.0 & 19.0 \\
\hline & 5 Sometimes true & 5 & 22.7 & 23.8 & 42.9 \\
\hline & 6 Usually true & 7 & 31.8 & 33.3 & 76.2 \\
\hline & 7 Always true & 5 & 22.7 & 23.8 & 100 \\
\hline & Total & 21 & 95.5 & 100 & \\
\hline Missing & System & 1 & 4.5 & & \\
\hline \multicolumn{2}{|l|}{ Total } & 22 & 100 & & \\
\hline \multicolumn{6}{|c|}{ S6: I get along with people at work. } \\
\hline & & Frequency & Percent & Valid \% & Cumulative $\%$ \\
\hline \multirow{8}{*}{ Valid } & 1 Never true & 0 & 0 & 0 & 0 \\
\hline & 2 Rarely true & 0 & 0 & 0 & 0 \\
\hline & 3 Infrequently true & 0 & 0 & 0 & 0 \\
\hline & 4 Neutral & 3 & 13.6 & 14.3 & 14.3 \\
\hline & 5 Sometimes true & 4 & 18.2 & 19.0 & 33.3 \\
\hline & 6 Usually true & 8 & 36.4 & 38.1 & 71.4 \\
\hline & 7 Always true & 6 & 27.3 & 28.6 & 100 \\
\hline & Total & 21 & 95.5 & 100 & \\
\hline Missing & System & 1 & 4.5 & & \\
\hline \multicolumn{2}{|c|}{ Total } & 22 & 100 & & \\
\hline \multicolumn{6}{|c|}{ S7: I pretty much keep to myself when I am at work. } \\
\hline \multirow{9}{*}{ Valid } & & Frequency & Percent & Valid \% & Cumulative $\%$ \\
\hline & 1 Never true & 0 & 0 & 0 & 0 \\
\hline & 2 Rarely true & 0 & 0 & 0 & 0 \\
\hline & 3 Infrequently true & 0 & 0 & 0 & 0 \\
\hline & 4 Neutral & 1 & 4.5 & 4.8 & 4.8 \\
\hline & 5 Sometimes true & 5 & 22.7 & 23.8 & 28.6 \\
\hline & 6 Usually true & 8 & 36.4 & 38.1 & 66.7 \\
\hline & 7 Always true & 7 & 31.8 & 33.3 & 100 \\
\hline & Total & 21 & 95.5 & 100 & \\
\hline Missing & System & 1 & 4.5 & & \\
\hline \multicolumn{2}{|c|}{ Total } & 22 & 100 & & \\
\hline \multicolumn{6}{|c|}{ S8: I am free to express my ideas and opinions on the job. } \\
\hline \multirow{8}{*}{ Valid } & & Frequency & Percent & Valid \% & Cumulative $\%$ \\
\hline & 1 Never true & 0 & 0 & 0 & 0 \\
\hline & 2 Rarely true & 0 & 0 & 0 & 0 \\
\hline & 3 Infrequently true & 1 & 4.5 & 4.8 & 4.8 \\
\hline & 4 Neutral & 1 & 4.5 & 4.8 & 9.5 \\
\hline & 5 Sometimes true & 5 & 22.7 & 23.8 & 33.3 \\
\hline & 6 Usually true & 7 & 31.8 & 33.3 & 66.7 \\
\hline & 7 Always true & 7 & 31.8 & 33.3 & 100 \\
\hline
\end{tabular}




\begin{tabular}{|c|c|c|c|c|c|}
\hline & Total & 21 & 95.5 & 100 & \\
\hline Missing & System & 1 & 4.5 & & \\
\hline \multicolumn{2}{|c|}{ Total } & 22 & 100 & & \\
\hline \multicolumn{6}{|c|}{ S9: I consider the people I work with to be my friends. } \\
\hline & & Frequency & Percent & Valid \% & Cumulative $\%$ \\
\hline \multirow{8}{*}{ Valid } & 1 Never true & 0 & 0 & 0 & 0 \\
\hline & 2 Rarely true & 0 & 0 & 0 & 0 \\
\hline & 3 Infrequently true & 0 & 0 & 0 & 0 \\
\hline & 4 Neutral & 0 & 0 & 0 & 0 \\
\hline & 5 Sometimes true & 3 & 13.6 & 14.3 & 14.3 \\
\hline & 6 Usually true & 2 & 9.1 & 9.5 & 23.8 \\
\hline & 7 Always true & 16 & 72.7 & 76.2 & 100 \\
\hline & Total & 21 & 95.5 & 100 & \\
\hline Missing & System & 1 & 4.5 & & \\
\hline \multicolumn{2}{|l|}{ Total } & 22 & 100 & & \\
\hline
\end{tabular}

S10: I have been able to learn interesting new skills on my job.

\begin{tabular}{|c|c|c|c|c|c|}
\hline & & Frequency & Percent & Valid \% & Cumulative $\%$ \\
\hline \multirow{8}{*}{ Valid } & 1 Never true & 0 & 0 & 0 & 0 \\
\hline & 2 Rarely true & 0 & 0 & 0 & 0 \\
\hline & 3 Infrequently true & 0 & 0 & 0 & 0 \\
\hline & 4 Neutral & 0 & 0 & 0 & 0 \\
\hline & 5 Sometimes true & 3 & 13.6 & 14.3 & 14.3 \\
\hline & 6 Usually true & 2 & 9.1 & 9.5 & 23.8 \\
\hline & 7 Always true & 16 & 72.7 & 76.2 & 100 \\
\hline & Total & 21 & 95.5 & 100 & \\
\hline Missing & System & 1 & 4.5 & & \\
\hline \multicolumn{2}{|l|}{ Total } & 22 & 100 & & \\
\hline \multicolumn{6}{|c|}{ S11: When I am at work, I have to do what I am told. } \\
\hline & & Frequency & Percent & Valid \% & Cumulative $\%$ \\
\hline \multirow{8}{*}{ Valid } & 1 Never true & 0 & 0 & 0 & 0 \\
\hline & 2 Rarely true & 0 & 0 & 0 & 0 \\
\hline & 3 Infrequently true & 1 & 4.5 & 4.8 & 4.8 \\
\hline & 4 Neutral & 2 & 9.1 & 9.5 & 14.3 \\
\hline & 5 Sometimes true & 2 & 9.1 & 9.5 & 23.8 \\
\hline & 6 Usually true & 3 & 13.6 & 14.3 & 38.1 \\
\hline & 7 Always true & 13 & 59.1 & 61.9 & 100 \\
\hline & Total & 21 & 95.5 & 100 & \\
\hline Missing & System & 1 & 4.5 & & \\
\hline \multicolumn{2}{|l|}{ Total } & 22 & 100 & & \\
\hline \multicolumn{6}{|c|}{ S12: Most days I feel a sense of accomplishment from working. } \\
\hline \multirow{8}{*}{ Valid } & 1 Never true & 0 & 0 & 0 & 0 \\
\hline & 2 Rarely true & 0 & 0 & 0 & 0 \\
\hline & 3 Infrequently true & 2 & 9.1 & 9.5 & 9.5 \\
\hline & 4 Neutral & 2 & 9.1 & 9.5 & 19 \\
\hline & 5 Sometimes true & 4 & 18.2 & 19.0 & 38.1 \\
\hline & 6 Usually true & 6 & 27.3 & 28.6 & 66.7 \\
\hline & 7 Always true & 7 & 31.8 & 33.3 & 100 \\
\hline & Total & 21 & 95.5 & 100 & \\
\hline Missing & System & 1 & 4.5 & & \\
\hline \multicolumn{2}{|c|}{ Total } & 22 & 100 & & \\
\hline \multicolumn{6}{|c|}{ S13: My feelings are taken into consideration at work. } \\
\hline & & Frequency & Percent & Valid \% & Cumulative $\%$ \\
\hline \multirow{2}{*}{ Valid } & 1 Never true & 0 & 0 & 0 & 0 \\
\hline & 2 Rarely true & 0 & 0 & 0 & 0 \\
\hline
\end{tabular}




\begin{tabular}{|c|c|c|c|c|c|}
\hline & 3 Infrequently true & 0 & 0 & 0 & 0 \\
\hline & 4 Neutral & 3 & 13.6 & 14.3 & 14.3 \\
\hline & 5 Sometimes true & 5 & 22.7 & 23.8 & 38.1 \\
\hline & 6 Usually true & 5 & 22.7 & 23.8 & 61.9 \\
\hline & 7 Always true & 8 & 36.4 & 38.1 & 100 \\
\hline & Total & 21 & 95.5 & 100 & \\
\hline Missing & System & 1 & 4.5 & & \\
\hline \multicolumn{2}{|c|}{ Total } & 22 & 100 & & \\
\hline \multicolumn{6}{|c|}{ S14: On my job I do not get much of a chance to show how capable I am. } \\
\hline & & Frequency & Percent & Valid \% & Cumulative $\%$ \\
\hline \multirow{8}{*}{ Valid } & 1 Never true & 2 & 9.1 & 9.5 & 9.5 \\
\hline & 2 Rarely true & 0 & 0 & 0 & 0 \\
\hline & 3 Infrequently true & 3 & 13.6 & 14.3 & 23.8 \\
\hline & 4 Neutral & 6 & 27.3 & 28.6 & 52.4 \\
\hline & 5 Sometimes true & 2 & 9.1 & 9.5 & 61.9 \\
\hline & 6 Usually true & 4 & 18.2 & 19 & 81 \\
\hline & 7 Always true & 4 & 18.2 & 19 & 100 \\
\hline & Total & 21 & 95.5 & 100 & \\
\hline Missing & System & 1 & 4.5 & & \\
\hline \multicolumn{2}{|c|}{ Total } & 22 & 100 & & \\
\hline \multicolumn{6}{|c|}{ S15: People at work care about me. } \\
\hline & & Frequency & Percent & Valid \% & Cumulative $\%$ \\
\hline \multirow{8}{*}{ Valid } & 1 Never true & 0 & 0 & 0 & 0 \\
\hline & 2 Rarely true & 0 & 0 & 0 & 0 \\
\hline & 3 Infrequently true & 2 & 9.1 & 9.5 & 9.5 \\
\hline & 4 Neutral & 4 & 18.2 & 19.0 & 28.6 \\
\hline & 5 Sometimes true & 5 & 22.7 & 23.8 & 52.4 \\
\hline & 6 Usually true & 5 & 22.7 & 23.8 & 76.2 \\
\hline & 7 Always true & 5 & 22.7 & 23.8 & 100 \\
\hline & Total & 21 & 95.5 & 100 & \\
\hline Missing & System & 1 & 4.5 & & \\
\hline \multicolumn{2}{|c|}{ Total } & 22 & 100 & & \\
\hline \multicolumn{6}{|c|}{ S16: There are not many people at work that I am close to. } \\
\hline & & Frequency & Percent & Valid \% & Cumulative $\%$ \\
\hline \multirow{8}{*}{ Valid } & 1 Never true & 2 & 9.1 & 9.5 & 9.5 \\
\hline & 2 Rarely true & 0 & 0 & 0 & 0 \\
\hline & 3 Infrequently true & 1 & 4.5 & 4.8 & 14.3 \\
\hline & 4 Neutral & 7 & 31.8 & 33.3 & 47.6 \\
\hline & 5 Sometimes true & 5 & 22.7 & 23.8 & 71.4 \\
\hline & 6 Usually true & 2 & 9.1 & 9.5 & 81 \\
\hline & 7 Always true & 4 & 18.2 & 19 & 100 \\
\hline & Total & 21 & 95.5 & 100 & \\
\hline Missing & System & 1 & 4.5 & & \\
\hline \multicolumn{2}{|l|}{ Total } & 22 & 100 & & \\
\hline \multicolumn{6}{|c|}{ S17: I feel like I can pretty much be myself at work. } \\
\hline & & Frequency & Percent & Valid \% & Cumulative $\%$ \\
\hline \multirow{8}{*}{ Valid } & 1 Never true & 0 & 0 & 0 & 0 \\
\hline & 2 Rarely true & 0 & 0 & 0 & 0 \\
\hline & 3 Infrequently true & 0 & 0 & 0 & 0 \\
\hline & 4 Neutral & 1 & 4.5 & 4.8 & 4.8 \\
\hline & 5 Sometimes true & 4 & 18.2 & 19.0 & 23.8 \\
\hline & 6 Usually true & 7 & 31.8 & 33.3 & 57.1 \\
\hline & 7 Always true & 9 & 40.9 & 42.9 & 100 \\
\hline & Total & 21 & 95.5 & 100 & \\
\hline Missing & System & 1 & 4.5 & & \\
\hline
\end{tabular}




\begin{tabular}{|c|c|c|c|c|c|}
\hline \multicolumn{2}{|c|}{ Total } & 22 & 100 & & \\
\hline \multicolumn{6}{|c|}{ S18: The people I work with do not seem to like me much. } \\
\hline \multirow{9}{*}{ Valid } & & Frequency & Percent & Valid \% & Cumulative $\%$ \\
\hline & 1 Never true & 4 & 18.2 & 19 & 19 \\
\hline & 2 Rarely true & 1 & 4.5 & 4.8 & 23.8 \\
\hline & 3 Infrequently true & 1 & 4.5 & 4.8 & 28.6 \\
\hline & 4 Neutral & 4 & 18.2 & 19 & 47.6 \\
\hline & 5 Sometimes true & 5 & 22.7 & 23.8 & 71.4 \\
\hline & 6 Usually true & 2 & 9.1 & 9.5 & 81 \\
\hline & 7 Always true & 4 & 18.2 & 19 & 100 \\
\hline & Total & 21 & 95.5 & 100 & \\
\hline Missing & System & 1 & 4.5 & & \\
\hline \multicolumn{2}{|c|}{ Total } & 22 & 100 & & \\
\hline \multicolumn{6}{|c|}{ S19: When I am working, I often do not feel very capable. } \\
\hline & & Frequency & Percent & Valid \% & Cumulative $\%$ \\
\hline \multirow{8}{*}{ Valid } & 1 Never true & 2 & 9.1 & 9.5 & 9.5 \\
\hline & 2 Rarely true & 2 & 9.1 & 9.5 & 19 \\
\hline & 3 Infrequently true & 2 & 9.1 & 9.5 & 28.6 \\
\hline & 4 Neutral & 7 & 31.8 & 33.3 & 61.9 \\
\hline & 5 Sometimes true & 5 & 22.7 & 23.8 & 85.7 \\
\hline & 6 Usually true & 1 & 4.5 & 4.8 & 90.5 \\
\hline & 7 Always true & 2 & 9.1 & 9.5 & 100 \\
\hline & Total & 21 & 95.5 & 100 & \\
\hline Missing & System & 1 & 4.5 & & \\
\hline \multicolumn{2}{|c|}{ Total } & 22 & 100 & & \\
\hline \multicolumn{6}{|c|}{ S20: There is not much opportunity for $m$} \\
\hline \multirow{8}{*}{ Valid } & 1 Never true & 2 & 9.1 & 9.5 & 9.5 \\
\hline & 2 Rarely true & 1 & 4.5 & 4.8 & 14.3 \\
\hline & 3 Infrequently true & 3 & 13.6 & 14.3 & 28.6 \\
\hline & 4 Neutral & 5 & 22.7 & 23.8 & 52.4 \\
\hline & 5 Sometimes true & 6 & 27.3 & 28.6 & 81 \\
\hline & 6 Usually true & 2 & 9.1 & 9.5 & 90.5 \\
\hline & 7 Always true & 2 & 9.1 & 9.5 & 100 \\
\hline & Total & 21 & 95.5 & 100 & \\
\hline Missing & System & 1 & 4.5 & & \\
\hline \multicolumn{2}{|c|}{ Total } & 22 & 100 & & \\
\hline \multicolumn{6}{|c|}{ S21: People at work are pretty friendly towards me. } \\
\hline \multirow{9}{*}{ Valid } & & Frequency & Percent & Valid \% & Cumulative $\%$ \\
\hline & 1 Never true & 1 & 4.5 & 4.8 & 4.8 \\
\hline & 2 Rarely true & 1 & 4.5 & 4.8 & 9.5 \\
\hline & 3 Infrequently true & 0 & 0 & 0 & 0 \\
\hline & 4 Neutral & 0 & 0 & 0 & 0 \\
\hline & 5 Sometimes true & 4 & 18.2 & 19 & 28.6 \\
\hline & 6 Usually true & 5 & 22.7 & 23.8 & 52.4 \\
\hline & 7 Always true & 10 & 45.5 & 47.6 & 100 \\
\hline & Total & 21 & 95.5 & 100 & \\
\hline Missing & System & 1 & 4.5 & & \\
\hline \multicolumn{2}{|l|}{ Total } & 22 & 100 & & \\
\hline
\end{tabular}




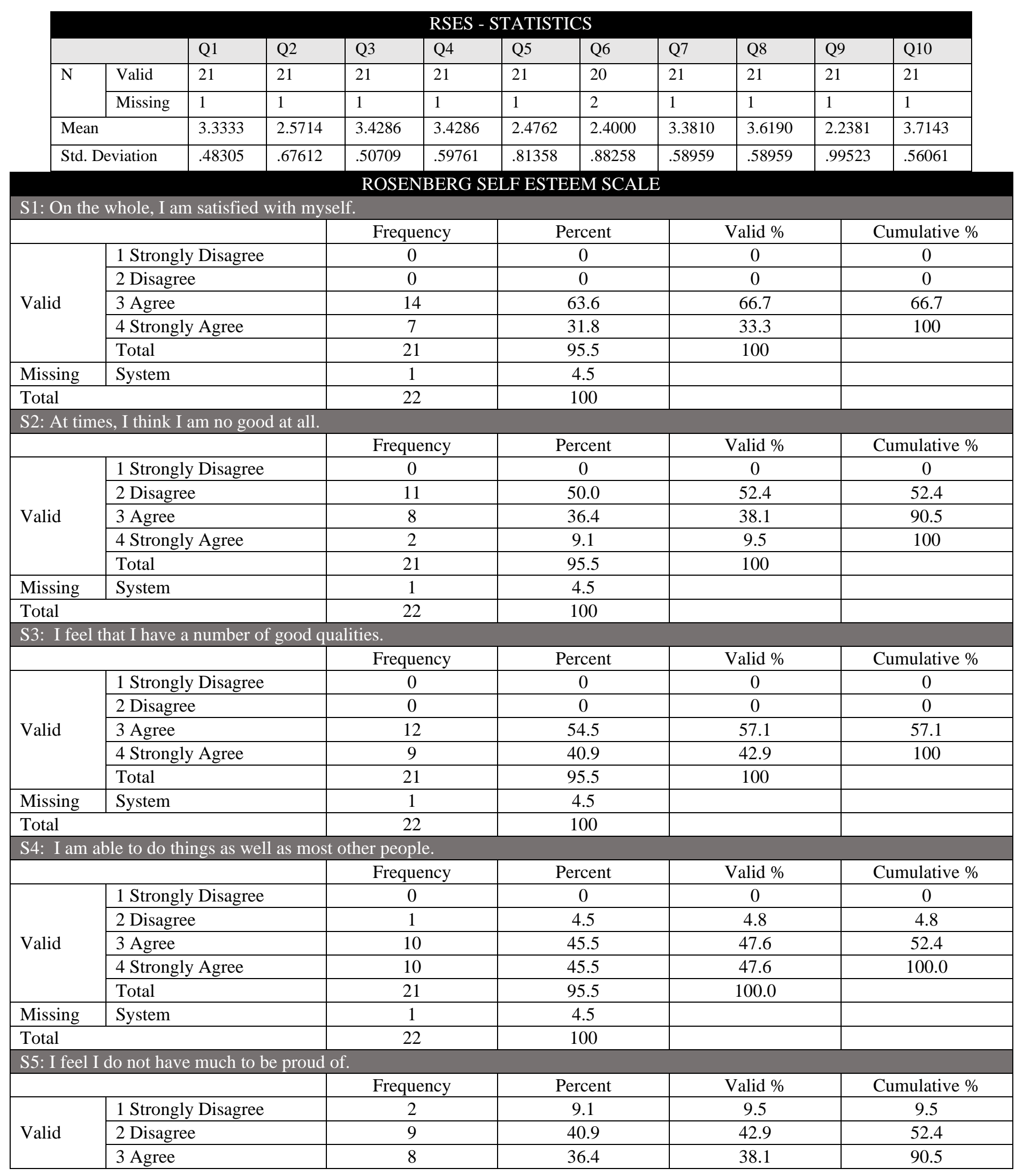




\begin{tabular}{|c|c|c|c|c|c|}
\hline & 4 Strongly Agree & 2 & 9.1 & 9.5 & 100 \\
\hline & Total & 21 & 95.5 & 100 & \\
\hline Missing & System & 1 & 4.5 & & \\
\hline \multicolumn{2}{|l|}{ Total } & 22 & 100 & & \\
\hline \multicolumn{6}{|c|}{ S6: I certainly feel useless at times. } \\
\hline & & Frequency & Percent & Valid \% & Cumulative $\%$ \\
\hline \multirow{5}{*}{ Valid } & 1 Strongly Disagree & 3 & 13.6 & 15 & 15 \\
\hline & 2 Disagree & 8 & 36.4 & 40 & 55 \\
\hline & 3 Agree & 7 & 31.8 & 35 & 90 \\
\hline & 4 Strongly Agree & 2 & 9.1 & 10 & 100 \\
\hline & Total & 20 & 90.9 & 100 & \\
\hline Missing & System & 2 & 9.1 & & \\
\hline \multicolumn{2}{|c|}{ Total } & 22 & 100 & & \\
\hline \multicolumn{6}{|c|}{ S7: I feel that I'm a person of worth, at least on an equal plane with others. } \\
\hline & & Frequency & Percent & Valid \% & Cumulative \% \\
\hline \multirow{5}{*}{ Valid } & 1 Strongly Disagree & 0 & 0 & 0 & 0 \\
\hline & 2 Disagree & 1 & 4.5 & 4.8 & 4.8 \\
\hline & 3 Agree & 11 & 50 & 52.4 & 57.1 \\
\hline & 4 Strongly Agree & 9 & 40.9 & 42.9 & 100 \\
\hline & Total & 21 & 95.5 & 100 & \\
\hline Missing & System & 1 & 4.5 & & \\
\hline \multicolumn{2}{|c|}{ Total } & 22 & 100 & & \\
\hline \multicolumn{6}{|c|}{ S8: I wish I could have more respect for myself. } \\
\hline & & Frequency & Percent & Valid \% & Cumulative $\%$ \\
\hline \multirow{5}{*}{ Valid } & 1 Strongly Disagree & 0 & 0 & 0 & 0 \\
\hline & 2 Disagree & 1 & 4.5 & 4.8 & 4.8 \\
\hline & 3 Agree & 6 & 27.3 & 28.6 & 33.3 \\
\hline & 4 Strongly Agree & 14 & 63.6 & 66.7 & 100 \\
\hline & Total & 21 & 95.5 & 100 & \\
\hline Missing & System & 1 & 4.5 & & \\
\hline \multicolumn{2}{|c|}{ Total } & 22 & 100 & & \\
\hline \multicolumn{6}{|c|}{ S9: All in all, I am inclined to feel that I am a failure. } \\
\hline & & Frequency & Percent & Valid \% & Cumulative $\%$ \\
\hline \multirow{5}{*}{ Valid } & 1 Strongly Disagree & 6 & 27.3 & 28.6 & 28.6 \\
\hline & 2 Disagree & 6 & 27.3 & 28.6 & 57.1 \\
\hline & 3 Agree & 7 & 31.8 & 33.3 & 90.5 \\
\hline & 4 Strongly Agree & 2 & 9.1 & 9.5 & 100 \\
\hline & Total & 21 & 95.5 & 100 & \\
\hline Missing & System & 1 & 4.5 & & \\
\hline \multicolumn{2}{|c|}{ Total } & 22 & 100 & & \\
\hline \multicolumn{6}{|c|}{ S10: I take a positive attitude toward myself. } \\
\hline & & Frequency & Percent & Valid \% & Cumulative $\%$ \\
\hline \multirow{5}{*}{ Valid } & 1 Strongly Disagree & 0 & 0 & 0 & 0 \\
\hline & 2 Disagree & 1 & 4.5 & 4.8 & 4.8 \\
\hline & 3 Agree & 4 & 18.2 & 19 & 23.8 \\
\hline & 4 Strongly Agree & 16 & 72.7 & 76.2 & 100 \\
\hline & Total & 21 & 95.5 & 100 & \\
\hline Missing & System & 1 & 4.5 & & \\
\hline \multicolumn{2}{|l|}{ Total } & 22 & 100 & & \\
\hline
\end{tabular}

